\title{
REVISTAMARACANAN
}

Dossiê

\section{A imagem da cidade: o centro comercial de Campo Grande, Rio de Janeiro, no século XXI}

\author{
The image of the city: the commercial center of Campo Grande, Rïo de \\ Janeiro, in the 21st century
}

Paulo Henrique de Araújo Barata* Secretaria de Estado de Educação do Rio de Janeiro

Rio de Janeiro, Rio de Janeiro, Brasil

Recebido em: 12 jan. 2020.

Aprovado em: 12 maio 2020.

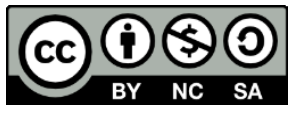

\footnotetext{
* Professor Docente I - Geografia da Secretaria de Estado de Educação do Rio de Janeiro. Doutor e Mestre em Geografia pela Universidade do Estado do Rio de Janeiro; Especialista em Políticas Territoriais do Estado do Rio de Janeiro pela Universidade do Estado do Rio de Janeiro; graduado em Geografia pelas Faculdades Integradas Simonsen e em Complementação Pedagógica em Língua Inglesa pela Universidade Castelo Branco. (phabarata@gmail.com)

ORCID iD: https://orcid.org/0000-0003-3316-1620

CV Lattes: http://lattes.cnpq.br/2284897607396575
} 


\title{
Resumo
}

O artigo objetiva a descrição da atual organização do espaço comercial do centro de Campo Grande, Rio de Janeiro, e ruas adjacentes, e identificação das evidências de acúmulo de tempos desiguais que formam a paisagem e o espaço urbano hodierno do bairro. A partir dos elementos espaciais materializados como objetos buscamos compreender as ações realizadas nesse recorte espacial ao longo do tempo. Para atingir tal fim usamos a descrição e, por conseguinte, utilizamos a metodologia de leitura da imagem da cidade de Kevin Lynch para adquirir e interpretar a imagem atual do centro comercial tipicamente urbano de um bairro outrora rural. Identificamos a consolidação dos objetos tipicamente urbanos sobre os rurais, e a refuncionalização dos objetos rurais para as atividades urbanas.

Palavras-chave: Campo Grande. Centro Comercial. Paisagem Urbana. Espaço Urbano. Rugosidades.

\begin{abstract}
The article aims to describe the current organization of the commercial space in the center of Campo Grande, and adjacent streets, and to identify the evidence of accumulation of unequal times that form the landscape and the horde of the neighborhood. From the spatial elements materialized as objects, we seek to understand the actions carried out in this spatial framework over time. To achieve this, we use the description and, therefore, we use the Kevin Lynch city image reading methodology to acquire and interpret the current image of the typically urban shopping center in a once rural neighborhood. We identified the consolidation of typically urban objects over rural ones, and the refunctionalization of rural objects for urban activities.
\end{abstract}

Keywords: Campo Grande. Commercial Center. Urban Landscape. Urban Space. Roughness. 
Isso aqui me sufoca hoje em dia.

Maria Cristina Bastos Lima.

Campo Grande é um dos bairros da Zona Oeste do Rio de Janeiro, antiga Zona Rural ou Sertão Carioca como a região era conhecida. A imagem de Sertão continuou na memória tanto daqueles que habitavam o bairro quanto aqueles que acompanhavam sua história de longe. $A$ sensação de sufocamento de Maria Cristina Bastos Lima, herdeira da família Bastos, importante liderança política e cultural do bairro de Campo Grande no século XX, é reflexo do testemunho da passagem da aparente calmaria e aspecto bucólico do passado rural para o adensamento de objetos, ações e fluxos que compõem o espaço urbano campograndense nos dias de hoje. "A cidade [...] é o produto de muitos construtores que constantemente modificam a estrutura por razões particulares [...] Não existe um resultado final, mas somente uma contínua sucessão de fases". ${ }^{1}$

O centro comercial de Campo Grande é o coração de um bairro com 328.370 mil habitantes em 122.414 domicílios, segundo o Censo IBGE 2010. É o bairro mais populoso da cidade do Rio de Janeiro, terceira maior extensão territorial com 119,13 km.2 , atrás apenas dos bairros de Guaratiba e Santa Cruz, respectivamente e com Índice de Desenvolvimento Humano de 0,810, considerado alto pela classificação do Programa das Nações Unidas para o Desenvolvimento (PNUD). ${ }^{2}$ Localizado na Zona Oeste da cidade, o bairro está a 53 quilômetros do Centro do Rio de Janeiro, aproximadamente uma hora de viagem de carro pela BR-101, que no seu trecho na cidade do Rio de Janeiro é batizada de Avenida Brasil - referência para os suburbanos em geral no deslocamento pela cidade.

\footnotetext{
${ }^{1}$ LYNCH, Kevin. A imagem da cidade. São Paulo: Martins Fontes, 1999, p. 12.

2 Índice de Desenvolvimento Humano Municipal (IDH), por ordem de IDH, segundo os bairros ou grupo de bairros - 2000. DataRio. Rio de Janeiro: Prefeitura da Cidade do Rio de Janeiro - Secretaria Municipal de Urbanismo - Instituto Pereira Passos - Diretoria de Informações Geográficas: 2010. Disponível em: http://www.data.rio/datasets/58186e41a2ad410f9099af99e46366fd. Acesso em: 19 fev. 2019; População - Bairro: Campo Grande. Bairros Cariocas. (Recurso Eletrônico). Rio de Janeiro: Prefeitura da Cidade do Rio de Janeiro - Secretaria Municipal de Urbanismo - Instituto Pereira Passos / Diretoria de Informações Geográficas. Disponível em: http://pcrj.maps.arcgis.com/apps/MapJournal/index.html?appid=7fe1b0d463e34b3b9ca2fafd50c3df76\# . Acesso em: 19 fev. 2019.
} 
Figura 1 - Localização do bairro de Campo Grande na Região Metropolitana do Rio de Janeiro.

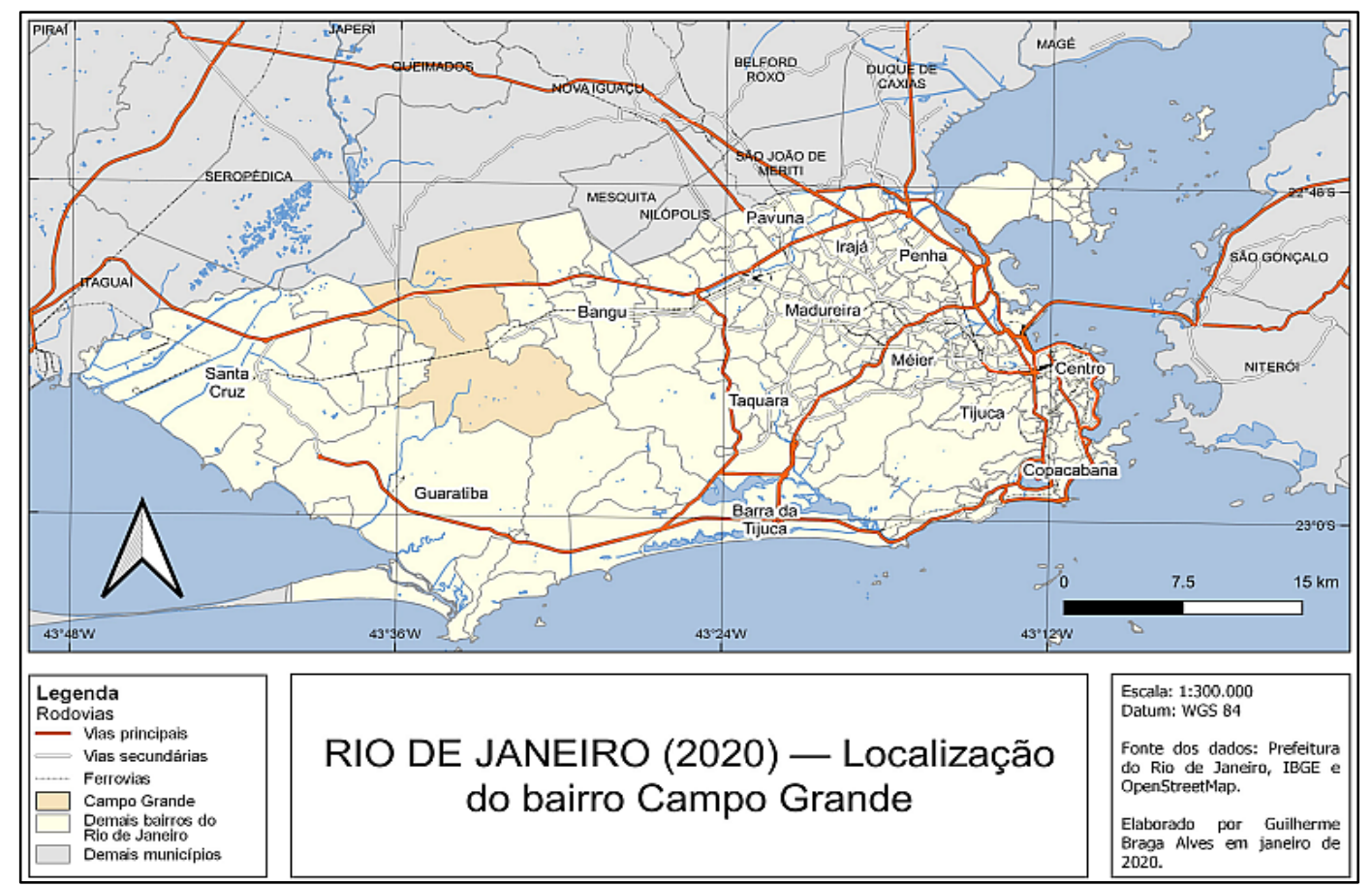

Fonte: ALVES, Guilherme Braga. Localização do bairro de Campo Grande na Região Metropolitana do Rio de Janeiro. 2020. Não publicado.

É delimitado pelos bairros de Augusto Vasconcelos, Santíssimo a leste, Inhoaíba a oeste e Guaratiba ao sul. Ao norte faz limite com a cidade de Nova Iguaçu, conectado a essa cidade pela antiga Estrada Rio-São Paulo A conjunção desses fatores o torna um bairro com indicadores populacionais e extensão territorial superiores a maioria das cidades do território nacional. São características amplas e superficiais meramente estatísticas e descritivas mas que permitem o vislumbre de um recorte complexo, mas cuja análise está além daquilo que propomos para esse momento. A nossa lupa de análise foca no centro comercial de Campo Grande, que corresponde a uma área material igualmente densa e complexa mas com outros dados quantitativos e, especialmente, qualitativos a serem obtidos para a formação da imagem do bairro.

O artigo, extraído de tese baseada no método regressivo-progressivo de Henri Lefebvre para a análise da transformação do espaço rural ao urbano, corresponde a realização da primeira etapa do método lefebvriano. ${ }^{3} 0$ objetivo é descrever a atual organização do espaço

3 LEFEBVRE, Henri. De lo rural a lo urbano. Barcelona: Península, 1978. Lefebrve estabelece três
momentos para o seu método. "No primeiro momento ocorre a descrição do espaço atual baseado em
empiria alinhando com uma teoria geral baseado em entrevistas, questionários e estatísticas. [...] O
segundo momento é o analítico-regressivo, que prevê a análise da realidade descrita, sem fechá-la
totalmente, isto é, deverão ser consideradas as contradições e as possibilidades. [...] O terceiro momento
previsto pelo método é o histórico-genético, fase também conhecida como regressiva-progressiva, onde
reencontramos o presente já descrito, retomando as modificações que a estrutura nos apresenta. Trata-
se do momento em que buscaremos a gênese das formações dessas estruturas, apontando um marco
geral de transformação sem perder o processo de conjunto. Segundo Lefebvre (1978), é imprescindível
nesse método considerar a interação das estruturas, a influência das estruturas recentes sobre as
estruturas antigas subordinadas ou integradas às primeiras". GODOY, Paulo Roberto Teixeira (org.). 
campograndense como acúmulo de tempos resultando na paisagem e no espaço atual do bairro. A descrição atual do centro comercial de Campo Grande, e seu entorno próximo, é obtida pela observação baseada na experiência ancorada a uma teoria geral associada a entrevistas, questionários e estatísticas. Apesar das diferenças de suas bases teóricas, entrelaçamos as similitudes metodológicas entre o proposto por Lefebvre e a metodologia elaborada por Kevin Lynch, para a aquisição da imagem da cidade - que torna-se importante ferramenta para a compreensão das ações e objetos implantados pelas ações engendradas no recorte espaço-temporal.

A descrição da paisagem urbana é baseada nos conceitos principais da análise da imagem da cidade que são, entre outros, a legibilidade, a identidade e a estrutura.

A legibilidade é a facilidade com a qual partes da cidade podem ser reconhecidas e organizadas numa estrutura coerente. Uma cidade legível seria aquela cujas freguesias, sinais de delimitação ou vias são facilmente identificáveis e passíveis de agrupamento em estruturas globais [...] A identidade é a individualidade ou particularidade dos objetos. A identificação de um objeto implica a sua distinção de outras coisas, o seu reconhecimento como uma entidade separável [...] A estrutura refere-se a relação de dado objeto com o observador e com os outros objetos. $^{4}$

Os conceitos e, por conseguinte, as imagens da cidade são estruturados a partir dos elementos constituintes da paisagem que as pessoas utilizam como base para a sua elaboração da imagem subjetiva a cada ser humano. Tais elementos são agrupados em cinco tipos: vias, limites, bairros, cruzamentos e pontos marcantes.

\begin{abstract}
Vias são os canais ao longo dos quais o observador se move, usual, ocasional ou potencialmente. Podem ser ruas, passeios, linhas de trânsito, canais, caminhos de ferro [...] As pessoas observam a cidade à medida que nela se deslocam e os outros elementos organizam-se e relacionam-se ao longo destas vias [...].

Limites são os elementos lineares não usados nem considerados pelos habitantes como vias. São as fronteiras entre duas partes, interrupções lineares na continuidade [...] cortes das estradas de ferro, paredes, locais de desenvolvimento. Funcionam, no fundo, mais como referências secundárias do que como alavancas coordenantes; tais limites podem ser [...] costuras, linhas ao longo das quais regiões se relacionam e encontram. Estes elementos limites [...] são, para muitos, uma relevante característica organizadora, particularmente quando se trata de manter unidas áreas diversas [...].

Bairros são regiões urbanas de tamanho médio ou grande, concebidos como tendo uma extensão bidimensional, regiões essas em que o observador penetra mentalmente e que reconhece como tendo algo de comum e identificável [...] Cruzamentos são pontos, locais estratégicos de uma cidade, através dos quais o observador nela pode entrar e constituem intensivos focos para os quais e dos quais ele se desloca [...] Alguns destes nós de concentração são ou o foco ou o "resumo" de um bairro. É destes nós que a sua influência irradia muitas vezes, tornando-se, por vezes, um cruzamento o símbolo de um bairro. Podem, por isto também, chamar-se "centros". Muitos destes nós partilham da natureza tanto das junções como das concentrações. O conceito de cruzamento está relacionado com o de via, pois os cruzamentos são típicas convergências de vidas, fatos do percurso. Estão, semelhantemente, ligados ao conceito de bairro, devido ao seu caráter de núcleo, que, por sua vez, é o foco intensivo, o centro polarizador do bairro. Em qualquer caso ou imagem, encontram-se pontos focais e, em alguns casos, eles são até a características dominante [...] Pontos
\end{abstract}

História do Pensamento Geográfico e epistemologia em Geografia. São Paulo: Ed. UNESP, 2010, p. 159161.

${ }^{4}$ LYNCH, Kevin. A imagem da cidade. Op. cit., p. 13-18. 
marcantes são representados por um objeto físico, definindo de um modo simples: edifício, sinal, loja ou montanha. O seu uso implica a sua distinção e evidência, em relação a uma quantidade enorme de outros elementos. ${ }^{5}$

Nenhum dos elementos existem isolados no espaço. "Os bairros contêm cruzamentos na sua estrutura, são demarcados por limites, cruzados por vias e salpicados por elementos marcantes. Os elementos sobrepõem-se e interligam-se constantemente". ${ }^{6}$ A reunião desses conceitos e elementos resulta a imagem do ambiente construído e, assim entendido, pelos sentidos e experiências dos indivíduos, mas, também, por outro lado ressalta a organização intrínseca e única desse espaço. Metodologicamente, Lynch aponta que, além das entrevistas com as pessoas que experienciam o espaço, é necessária a realização de um reconhecimento sistemático da área, que foi realizado via trabalhos de campo, que anote num mapa a presença de variados elementos, a sua visibilidade, a sua força ou fraqueza como imagem, as suas relações incoerentes e outras interligações. ${ }^{7}$ Deve-se registrar os lados positivos e negativos na estrutura da imagem potencial, pois opiniões são subjetivas e baseiam-se na aparência imediata destes elementos no terreno, e da empiria, obtida devido aos anos de circulação e observação do pesquisador no recorte em questão.

Todo o cidadão possui numerosas relações com algumas partes da sua cidade e a sua imagem estão impregnada de memórias e significações [...] Na maior parte das vezes, a nossa percepção da cidade não é íntegra, mas sim bastante parcial, fragmentária, envolvida noutras referências. Quase todos os sentidos estão envolvidos e a imagem é o composto resultante de todos eles. ${ }^{8}$

A ideia de retratar o centro comercial do bairro nos remete a ideia de Milton Santos sobre a relação espaço-paisagem. Santos dedica alguma atenção para definir e distinguir esses conceitos, que se entrelaçam e pelos quais é possível decodificar e compreender a produção humana em dado recorte. Segundo Santos, a paisagem é o conjunto de formas que, num dado momento, exprime as heranças que representam as sucessivas relações localizadas entre homem e natureza. ${ }^{9} \mathrm{~A}$ ideia é reforçada por Moraes ao asseverar que

Todos sabemos que as formas espaciais são produtos históricos. O espaço produzido é um resultado da ação humana sobre a superfície terrestre que expressa, a cada momento as relações sociais que lhe deram origem. Nesse sentido, a paisagem manifesta a historicidade do desenvolvimento humano, associando objetos fixados ao solo e geneticamente datados. Tais objetos exprimem a espacialidade de organizações sociopolíticas específicas e se articulam sempre numa funcionalidade do presente. ${ }^{10}$

Logo, podemos concluir que o espaço geográfico são essas formas mais a vida, em suas múltiplas dimensões que as anima. ${ }^{11} \mathrm{~A}$ partir dessa definição inicial, a análise da conjunção das formas-sociedade, ou seja, do binômio paisagem-espaço é aprofundada por Santos

\footnotetext{
${ }^{5}$ LYNCH, Kevin. A imagem da cidade... Op. cit., p. 58-59.

${ }^{6}$ Ibidem, p. 60.

7 Ibidem, passim.

${ }^{8}$ Ibidem, p. 12.

9 SANTOS, Milton. A Natureza do Espaço: Técnica e Tempo, Razão e Emoção. São Paulo: EdUSP, 2006, p. 66.

${ }^{10}$ MORAES, Antonio Carlos Robert. Ideologias Geográficas. São Paulo: Annablume, 2005, p. 15.

${ }^{11}$ SANTOS, Milton. A Natureza do Espaço... Op. cit., p. 66.
} 
expondo as diferenças e complementaridades entre os dois conceitos, aproximando-os e distinguindo-os para que sejam instrumentalizados para a compreensão do espaço geográfico. Assim, a imagem da cidade, a partir do caso do centro comercial do bairro, como propomos realizar nesse artigo, é uma descrição dos objetos concretos que compõem a paisagem, juntando formas produzidas por técnicas e objetivos específicos em tempos distintos que coexistem no presente. "O espaço, considerado como um mosaico de elementos de diferentes eras, sintetiza, de um lado a evolução da sociedade e explica, de outro lado, situações que se apresentam na atualidade. [...] a noção de espaço é assim inseparável da ideia de sistemas de tempo". ${ }^{12}$

Pois, qual é a imagem da cidade resultante dessa conjunção de objetos produzidos em tempos diferentes que forma e organiza o centro comercial do bairro, transbordando para as ruas das zonas residenciais no entorno imediato, nesse momento do século XXI?

Os habitantes do bairro de Campo Grande dividem o bairro em dois: "o lado de cá e o lado de lá". Os lados "de lá e de cá" são relativizados pelo "lado" no qual interlocutor esteja localizado. Todas as vezes que a questão dos "lados" é mencionada, emerge uma briga silenciosa e ensurdecedora: qual é o "lado de cá" e qual é o "lado de lá"? E, por que e como o bairro é dividido em dois lados? O porquê da divisão do bairro é de fácil resposta: a Estrada de Ferro Central do Brasil - ramal Santa Cruz. A linha ferroviária que conecta ao bairro a outros bairros e, especialmente, ao Centro da cidade do Rio de Janeiro, é o objeto a traçar o mais marcante limite intra-bairro. É a forma produzida pela ação humana que se tornou um obstáculo obrigando a construção de dois viadutos, que substituíram as antigas passagens de nível, uma passagem subterrânea e algumas passarelas de pedestres para conectar os "dois lados" do bairro.

As peculiaridades da produção do espaço do bairro Campo Grande, ao partir o bairro em duas porções, e o sistema de transporte interno baseado nas linhas rodoviárias obriga o morador de "um lado" a custear duas tarifas para chegar "do outro lado". Poucas linhas de ônibus e de transporte alternativo, chamadas de vans, estabelecem essa ligação cuja capacidade de passageiros, veículos disponíveis, questões (i)legais e afins limitam a interconexão dos loteamentos de ambos os lados no bairro. O peso do sistema de transporte devido ao intenso fluxo pelas vias é um traço marcante na paisagem e na produção do espaço ao longo do tempo.

A expressiva quantidade de linhas rodoviárias conectando o bairro a diferentes pontos da metrópole, e até extrapolando os limites administrativos da Região Metropolitana do Rio de Janeiro, revela a constituição e o estabelecimento do bairro como uma centralidade. As centralidades são mutáveis ao longo do tempo, pois existem diferentes variáveis que contribuem para a sua consolidação, como a rede viária e a produção do espaço para uso

${ }^{12}$ SANTOS, Milton. Espaço e método. São Paulo: Nobel, 1985, p. 21-22. 
específico de determinadas atividades, como o espaço comercial alimentado pelo constante fluxo rodoviário concentrado no terminal rodoviário do bairro e ruas adjacentes. ${ }^{13}$

Figura 2 - A delimitação do núcleo do centro comercial de Campo Grande (Zona de Comércio e Serviços 1 - ZCS1) pelo Projeto de Estruturação Urbana.

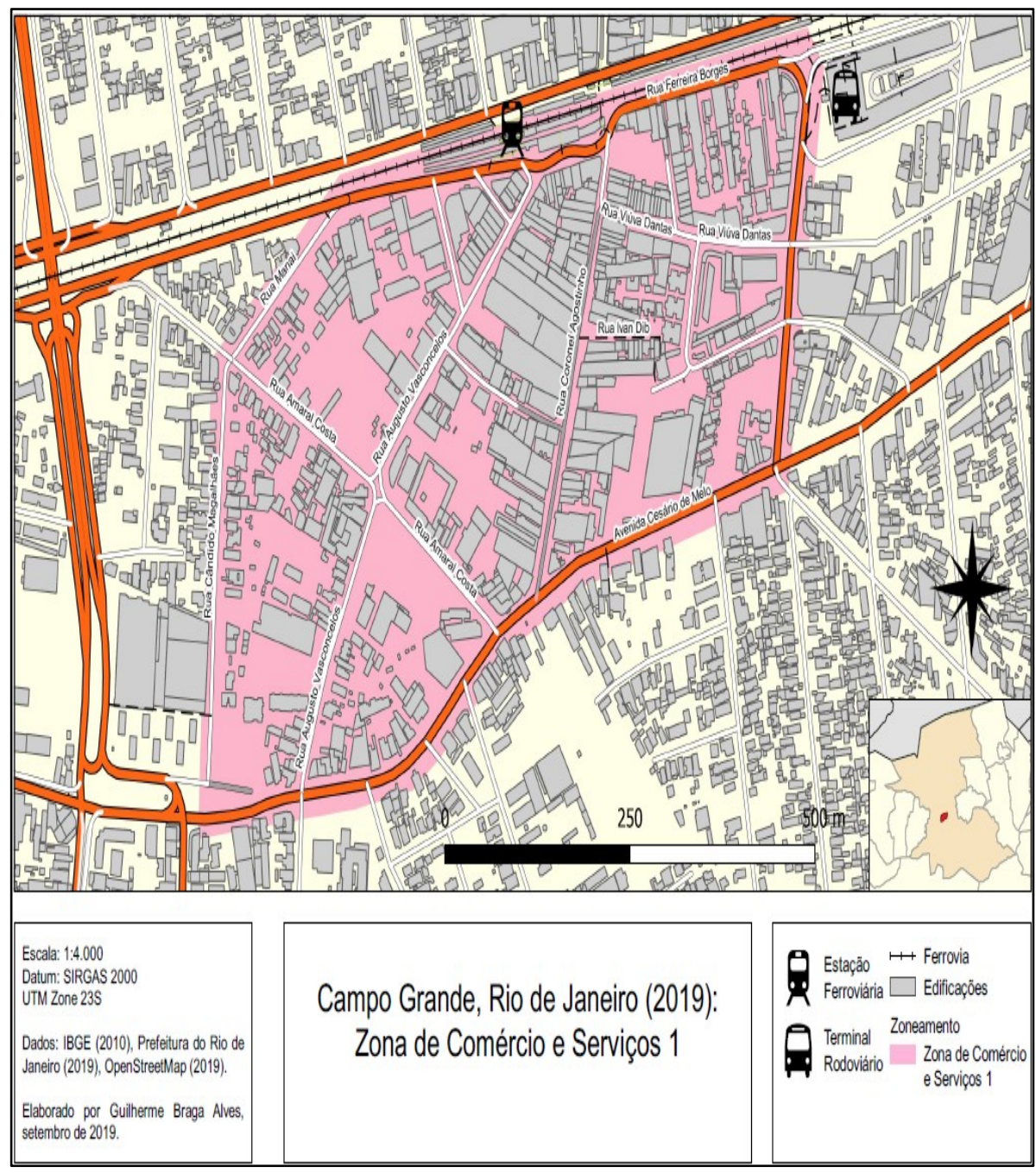

Fonte: RIO DE JANEIRO. Lei Complementar n. ${ }^{\circ}$ 72, de 27 de setembro de 2004, que institui o PEU Campo Grande; BARATA, Paulo Henrique Araujo. O Sertão vira Calçadão: A transformação do rural em urbano em Campo Grande, Rio de Janeiro, ao longo do século XX. 2019. Tese (Doutorado em Geografia)

- Instituto de Geografia da Universidade do Estado do Rio de Janeiro, Rio de Janeiro, p. 215.

A engenharia de trânsito cujo Projeto Binário, dentro do Programa Rio Cidade (Plano Estratégico I), concebeu a circulação de ônibus de maneira que dirimisse o impacto nas artérias mais comercialmente adensadas do centro comercial: a Zona de Comércio e Serviços 1 - como estabelecida pelo Projeto de Estrutura Urbana de Campo Grande (PEU de Campo Grande). Até a readequação das rotas das linhas de ônibus, após a construção do corredor

13 PINTAUDI, Silvana. Anotações sobre o espaço do comércio e do consumo. In: CARRERAS, Carles; PACHECO, Susana Mara Miranda. Cidade e comércio: a rua comercial na perspectiva internacional. Rio de Janeiro: Armazém das Letras, 2009, p. 58. 
BRT, as linhas circulavam sempre pelo anel mais externo possível da ZCS1: as ruas limítrofes dessa zona com a Zona de Comércio e Serviços 2 (ZCS2).

Tabela 1- Limitação da Zona de Comércio e Serviços 1.

\begin{tabular}{|c|c|}
\hline Vias limítrofes da ZCS1 & Vias internas da ZCS1 \\
\hline Rua Manaí - Rua Cândido Magalhães - & Rua Agostinho Coelho - Rua Augusto de \\
Avenida Cesário de Melo - Rua Aurélio de & Vasconcelos - Rua Coronel Agostinho - Rua Major \\
Figueiredo - Rua Xavier Marques - Rua & Almeida Costa - Rua Doutor Caetano de Faria \\
Ferreira Borges - Praça Dr. Raul & Castro - Rua José Ferreira - Rua Viúva Dantas - \\
Boaventura - Rua Engenheiro Trindade - & Travessa Ferreira Borges \\
Avenida Cesário de Melo & \\
\hline
\end{tabular}

Fonte: Google Maps, 2019. Elaborado pelo autor.

Tabela 2 - Limitação da Zona de Comércio e Serviços 2.

\begin{tabular}{|c|c|}
\hline Vias limítrofes da zCS2 & Vias internas da ZCS2 \\
\hline $\begin{array}{c}\text { Avenida Cesário de Melo - Estrada da } \\
\text { Estrada Rio do A - Avenida } \\
\text { Farroupilha }\end{array}$ & Rua Areinhas - Rodovia Luiz Henrique \\
& Rezende Novaes - Rua Jaboatão - Rua \\
Jaguaruna - Rua Barcelos Domingos - Rua \\
Santa Ermelinda - Rua Santo Eustáquio - \\
Travessa Barcelos Domingos - Rua Butiá - Rua \\
Campo Grande - Rua dos Franciscanos - Rua \\
Lucília - Rua Padre Pauvels - Rua Calicut - Rua \\
Manuel Ruivo - Rua Bertoldo Costa - Rua \\
Alaide Fróes - Rua Demerval Medeiros - Rua \\
Alain da Luz - Rua Vítor Alves - Rua Rosa de \\
Carvalho - Rua Oraida Perrota - Rua Albertina \\
- Rua Hildegarda Ribeiro - Rua Alfredo de \\
Morais - Rua Aracaju - Rua Gianerini - Rua \\
Cabo Móises de Oliveira - Travessa Soldado \\
Elídio Martins - Rua Soldado Ari Azevedo - \\
Rua Soldado Atualpa Leite Filho - Rua \\
Sargento Luís Rodrigues Filho - Rua Domingos \\
do Couto - Rua Ivo do Prado - Rua Amaral \\
Costa - Rua Carlos da Silva Costa - Rua \\
Milton Leão - Rua Cruz Alta - Rua Passo \\
Fundo - Rua Saquarema - Rua Erechim - Rua \\
Tiaraju - Rua João Telles - Rua Antero de \\
Souza - Travessa Manuel dos Santos - Rua \\
Projetada Um - Rua Professor José Oiticica - \\
Rua Viúva Dantas - Rua Iaçu - Rua Itaobim - \\
Rua Xavier Marques - Rua Dona Mafalda - \\
Rua Gregório da Fonseca - Rua Tab. Pinho \\
\hline
\end{tabular}

Fonte: Google Maps, 2019. Elaborado pelo autor.

Assim, as ruas Coronel Agostinho, Agostinho Coelho, a Rua Augusto de Vasconcelos em parte, Rua Major do Almeida Costa, Rua Viúva Dantas e Rua Doutor Caetano de Faria e Castro (além das travessas) são livres da circulação de transporte de massa, mesmo que 
algumas dessas vias ainda sejam povoadas pelo transporte individual, o que explica a existência de diversos terrenos funcionando como estacionamentos tanto no centro quanto nas áreas circundantes ao centro comercial.

Figura 3 - Estacionamentos nas ruas Alfredo de Morais e Amaral Costa, centro do bairro de Campo Grande, Rio de Janeiro

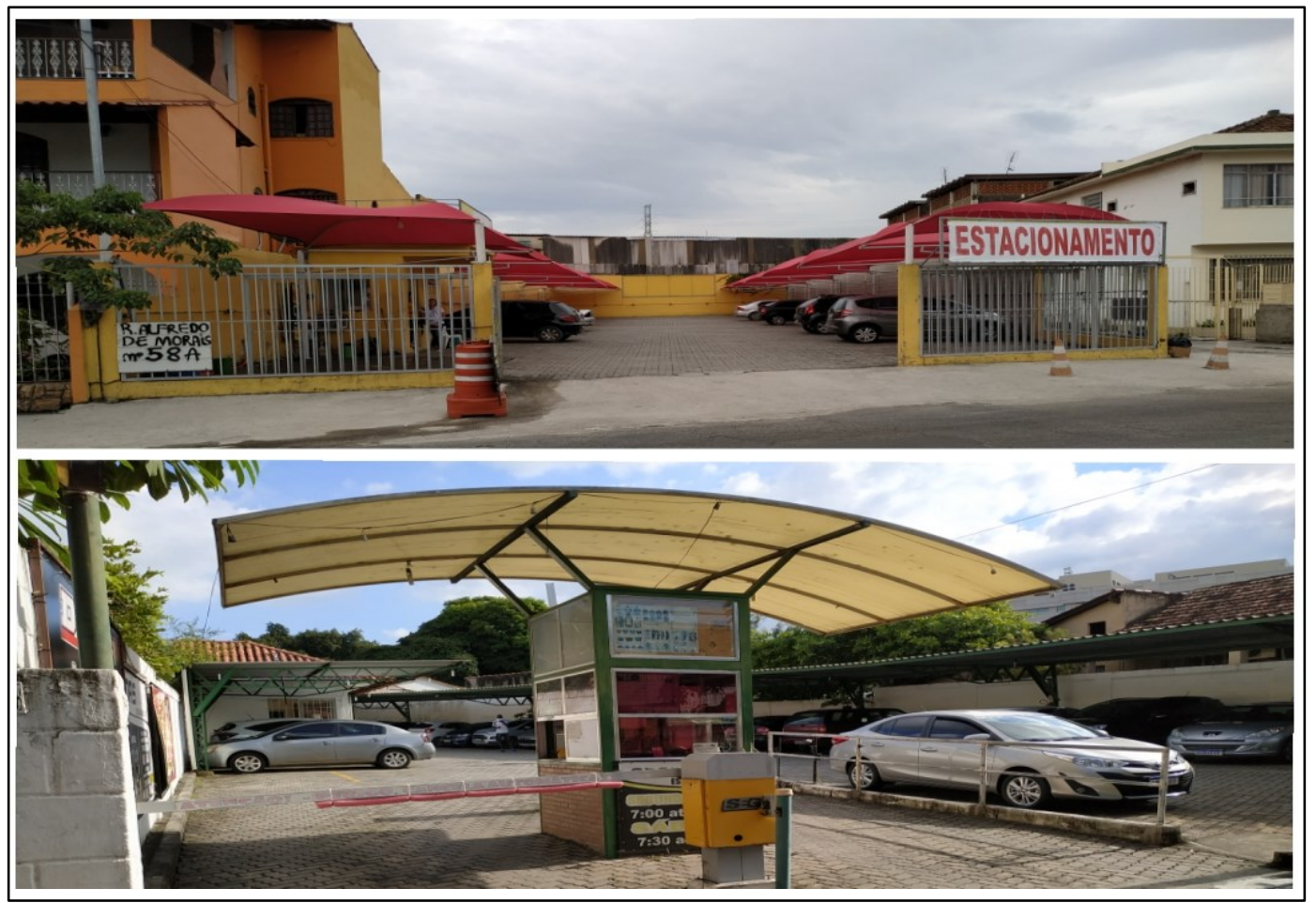

Fonte: BARATA, Paulo Henrique Araujo. O Sertão vira Calçadão... Op. cit., p. 40.

A localização do ponto final das linhas rodoviárias e do transporte alternativo apresenta uma tendência a concentração próxima a estação ferroviária de Campo Grande. Interessante notar que a localização da maior parte dos pontos finais das linhas de transporte alternativo é em estacionamentos ou galpões ou terrenos mal estruturados próximos aos pontos das mesmas linhas do transporte rodoviário, evidenciando a precarização dessa modalidade de transporte.

A linha férrea Estrada de Ferro Central do Brasil foi e ainda é o meio mais rápido de conexão entre o bairro de Campo Grande e o Centro do Rio de Janeiro. Conecta o bairro a todos os bairros cortados pela Estrada de Ferro Central do Brasil e dos outros ramais da malha ferroviária controlada pela Supervia. Exceto pela distância entre a estação ferroviária e a rodoviária do bairro, podemos apontar uma iniciativa de integração intermodal pela proximidade entre os pontos finais do transporte rodoviário, aí incluso o transporte alternativo de vans e pontos de táxi, e estação ferroviária em uma área, a Rua Campo Grande (transversais e paralelas), com considerável densidade comercial. As calçadas da Rua Campo Grande, especialmente as calçadas da estação, são "palcos de batalha" entre as filas dos usuários dos ônibus, as lojas de alimentação, utensílios domésticos, papelarias, lojas de 
móveis, entre outros, e as bancas do comércio de rua, que vendem de guloseimas a vestuário passando por gêneros alimentícios - como frutas e legumes. A marquise, que deveria proteger os usuários dos ônibus das intempéries e do calor do Sol durante o escorchante verão do bairro, causa maior temor que segurança ao cidadão mais atento. O seu estado de conservação está visivelmente degradado e clama por recuperação.

É da escadaria da estação ferroviária de Campo Grande que conseguimos enxergar as torres da Igreja Matriz Nossa Senhora do Desterro. A Igreja Matriz foi construída em terreno elevado forçando os pedestres a elevarem seu olhar aos céus para que possam contemplar o objeto religioso. A data da fundação do bairro é a mesma data da celebração de aniversário do bairro, tornando óbvia a importância desse objeto no tecido socioespacial e político no processo histórico e espacial de formação do bairro.

Figura 4 - Igreja Matriz Nossa Senhora do Desterro na Rua Almeida Costa, Campo Grande, Rio de Janeiro.

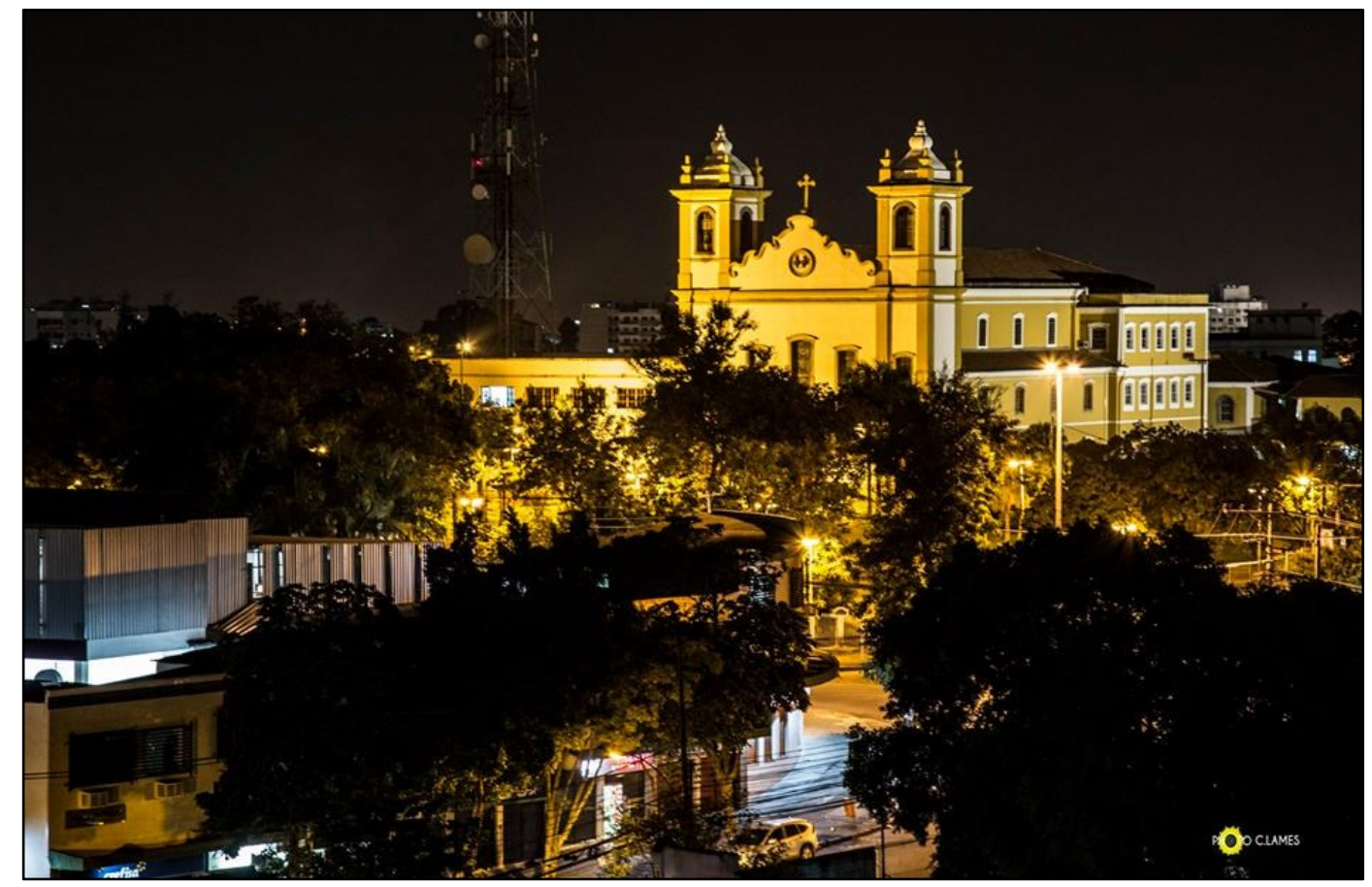

Fonte: LAMES, Cayo. Igreja Nossa Senhora dos Desterros. 2018. Facebook. (Plataforma Eletrônica). Disponível em: https://www.facebook.com/photo?fbid=361283014682673\&set=a. 122656968545280 Acesso em: 27 de dezembro de 2018.

A área ocupada e o tamanho da construção são consideráveis, ainda mais quando comparada aos outros objetos nas suas cercanias. O resultado é a sua visibilidade de diversos pontos do centro do bairro, que talvez fosse ainda mais visível anteriormente a construção de edificações que bloqueiam a sua imagem. Qualquer indivíduo avista a Igreja do Desterro com facilidade ao subir a escadaria da estação ferroviária de Campo Grande ou, com alguma dificuldade, circulando pelas ruas circunvizinhas ao templo religioso, como a Avenida Cesário de Melo, no trecho da Rua Olinda Elis em frente ao Campo Grande Shopping - no qual existe 
uma elevação natural que torna possível a visualização das torres da igreja - e por quase toda a extensão da Rua Amaral Costa, que corta a frente do terreno do templo. A observação em campo nos permite afirmar que não há outro objeto com arquitetura tão marcante e de mesmo tamanho e peso simbólico e cultural tão visível na paisagem do centro de Campo Grande.

Figura 5 - Espelhos da fachada do motel Agadir refletindo a imagem da Igreja Nossa Senhora do Desterro

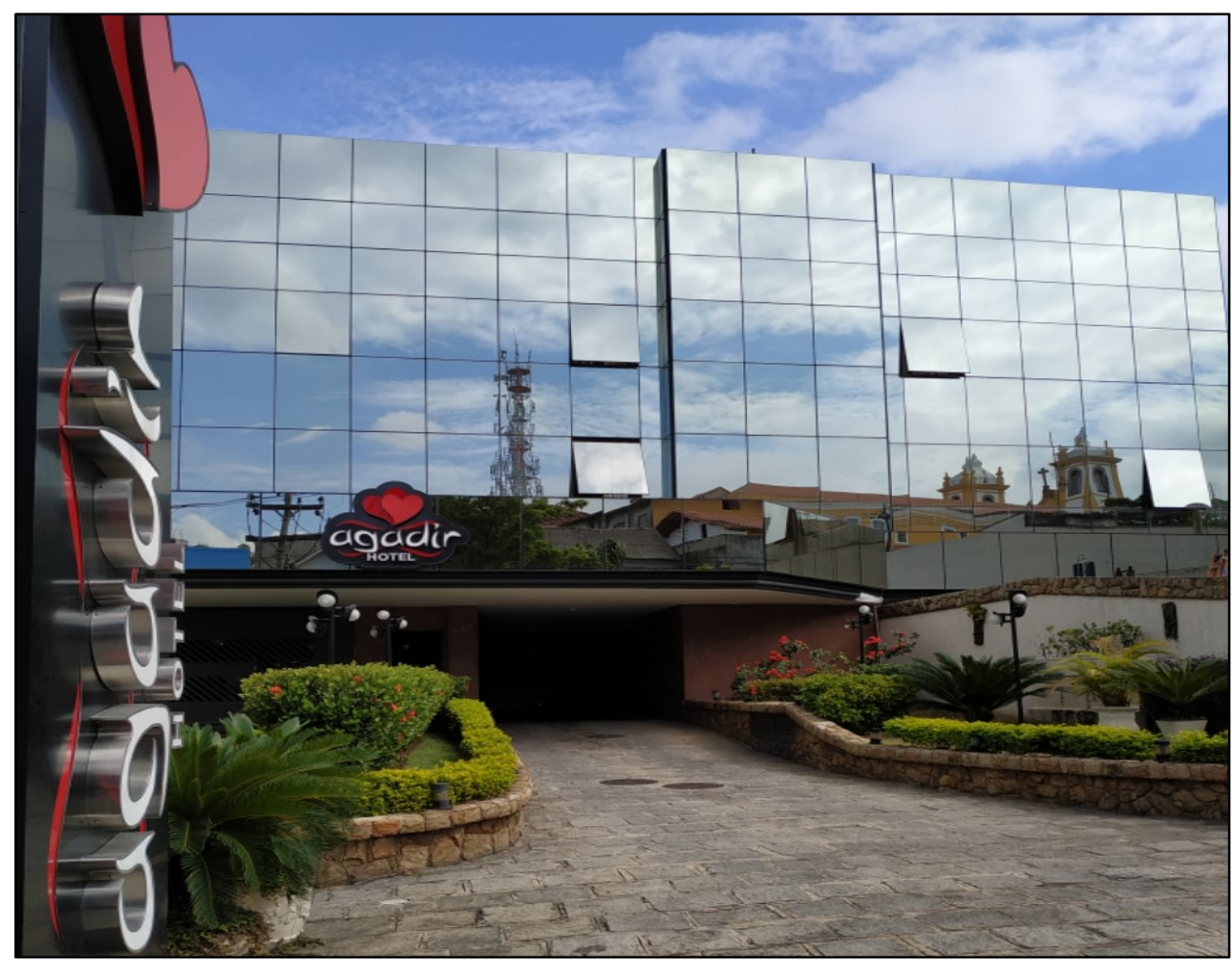

Fonte: BARATA, Paulo Henrique Araujo. O Sertão vira Calçadão... Op. cit., p. 43.

A imagem da Igreja do Desterro refletida na fachada espelhada do motel Agadir, dois objetos simbolicamente antagônicos, mas que coexistem separados por alguns passos de distância, é refletir sobre os diferentes interesses e momentos que moldam a paisagem do bairro no século XXI. Descer a Rua Augusto de Vasconcelos, e literalmente descer pois é uma pequena ladeira - no topo da qual a igreja e o motel foram construídos, é presenciar a perda da identidade continua e acelerada do centro comercial a medida que os interesses imobiliários avançam sobre as ruas e modificam ou obliteram as antigas formas, e vislumbrar uma futura paisagem distante daquela vista atualmente. Ao lado da igreja há um terreno vazio utilizado como estacionamento cuja extensão permite o acesso pela já citada rua e por outras duas: Amaral Costa e Francisco de Almeida Costa. Um olhar mais atento identifica resquícios de uma antiga construção nos muros e paredes das edificações vizinhas. Esses resquícios são tudo que sobrou do Colégio Belisário dos Santos, de propriedade da família de Helton Veloso, que por 71 anos, de 6 de março de 1941 até o último dia letivo de 2012, refuncionalizou a antiga 
residência do Padre Belisário dos Santos, responsável pela reconstrução da igreja após o incêndio de 1882, que a consumiu quase que completamente.

Figura 6 - Prédio e terreno do antigo Colégio Belisário dos Santos em funcionamento, posteriormente demolido e, finalmente, tornado estacionamento de carros na Rua Amaral Costa, Campo Grande - Rio de Janeiro.

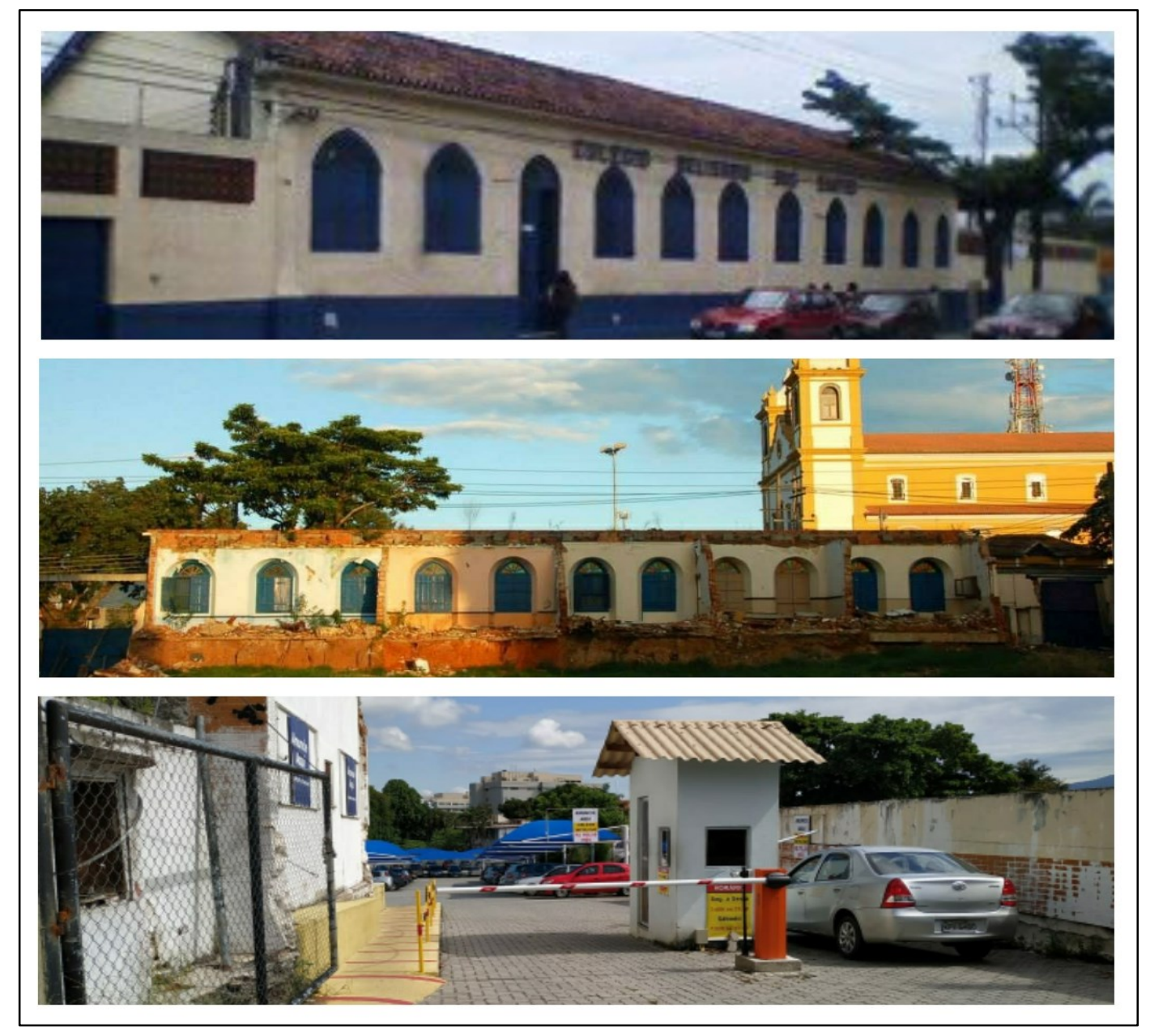

Fonte: Blog do Maninho Bonzão. (Blog). [Colégio Belisário Pena]. 2012. Disponível em: http://joseluizmano.blogspot.com/2012/08/ano-de-1952.html. Acesso em: 20 fev. 2019; RAVAGANI. [Colégio Belisário Pena]. [s./d.]. Disponível em: https://www.facebook.com/belisariocg/. Acesso em: 20 fev. 2019; BARATA, Paulo Henrique Araujo. O Sertão vira Calçadão... Op. cit., p. 44.

A derrubada do prédio facilita a visão dos prédios de arquitetura pós-moderna ao fundo. Esses novos prédios comerciais, que adotaram o padrão arquitetônico de fachada espelhada típico dos prédios comerciais europeus, se erguem no horizonte como "monstros" que lentamente destroem e, ao mesmo tempo, reconstroem a paisagem conferindo novas feições a paisagem e usos do espaço ao custo da História e da antiga identidade do bairro.

O encontro da Rua Augusto Vasconcelos com a Amaral Costa vem a seguir revelando outras formas que se não foram apagadas da paisagem, expõem a decadência da tradição familiar do bairro. Ao virar a esquerda na esquina das ruas citadas, no sentido de quem se dirige a linha ferroviária, permanece de pé o prédio mais recente do campus do antigo Centro Universitário Moacyr Sreder Bastos, atual Centro Universitário do Rio de Janeiro - UNIRJ. O 
complexo educacional, que também contava com a escola de educação básica batizada como Colégio Afonso Celso, ocupa a maior parte do quarteirão delimitado pelas ruas Engenheiro Trindade, Augusto de Vasconcelos, Agostinho Coelho, Rua Manaí e a Rua Amaral Costa. É um conjunto de 5 prédios destinados as salas de aulas e laboratórios, quadra poliesportiva, biblioteca e teatro. Quem passa em frente à entrada principal do complexo, na Rua Engenheiro Trindade, visualiza um muro construído no pátio. Há, literalmente, um muro construído no pátio principal dividindo o complexo em duas partes: aqueles que foram alugados pela UNIRJ e os outros que continuam sob a responsabilidade da família Bastos. Esses últimos, inclusive o teatro, estão em situação de visível abandono com pichações e jardinagem há muito não feita pela manutenção. A perda dos grandes objetos de serviços educacionais que ao longo das décadas tornaram-se referência é perder da memória e identidade do bairro.

Figura 7 - Prédios abandonados do Colégio Afonso Celso, na Rua Engenheiro Trindade, e Centro Universitário Moacyr Sreder Bastos, na Rua Amaral Costa, Campo Grande - Rio de Janeiro.

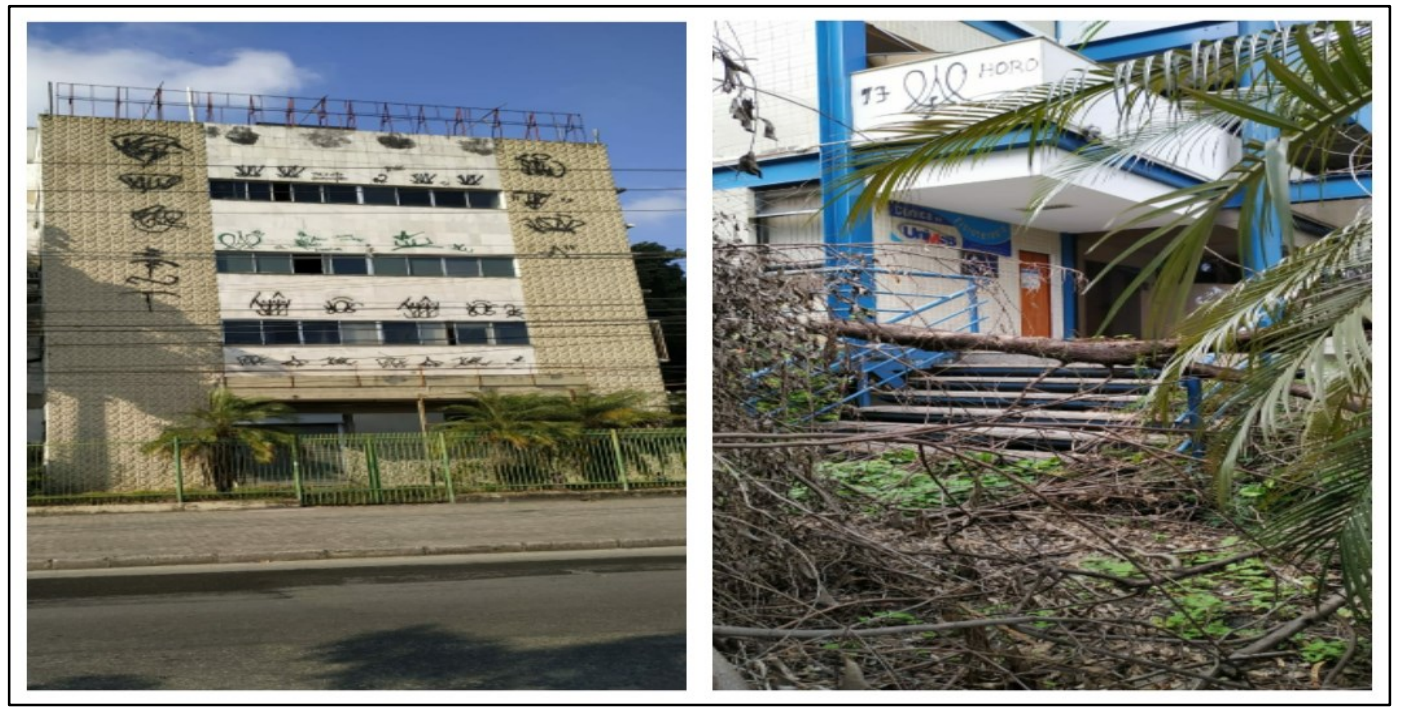

Fonte: BARATA, Paulo Henrique Araujo. O Sertão vira Calçadão... Op. cit., p. 46.

As rugosidades são objetos pretéritos que marcam a paisagem de maneira que tornamse a própria memória do espaço. A materialidade sobrevive revelando as bases sobre as quais o espaço foi construído ao longo do plano temporal. Pois, "chamemos de rugosidade ao que fica do passado como forma, espaço construído, paisagem, o que resta do processo de supressão, acumulação, superposição, com que as coisas se substituem e acumulam em todos os lugares". ${ }^{14}$ As rugosidades constituem-se fragmentos materiais das ações de uma sociedade pretérita sobre determinado substrato material revelando a sua organização e domínio das relações sociais.

as rugosidades nos oferecem, mesmo sem tradução imediata, restos de uma divisão de trabalho manifestada localmente por combinações particulares do

${ }^{14}$ SANTOS, Milton. A Natureza do Espaço... Op. cit., p. 140. 
capital, das técnicas e do trabalho utilizados [...]. O espaço, portanto, é um testemunho; ele testemunha um momento de um modo de produção pela memória do espaço construído, das coisas fixadas na paisagem criada. Assim o espaço é uma forma, uma forma durável, que não se desfaz paralelamente às mudanças de processos; ao contrário, alguns processos se adaptam às formas preexistentes enquanto que outros criam novas formas para se inserir dentro delas. ${ }^{15}$

Logo, feições do campo continuam visíveis seja pelos objetos sobreviventes ou pela implantação de objetos que remetam ao passado, como resgate da memória e imposição da história e da geografia que deseja-se como verdade. É possível perceber o casario inalterado com feições campestres cercados por objetos típicos da manifestação do urbano na cidade.

As ruas do entorno da Igreja Nossa Senhora do Desterro, nas Zonas Comerciais e Serviços 1 e 2 e na Zona Residencial 4, contém uma grande concentração de rugosidades na paisagem. Formas residenciais preservadas que ou mantém sua função original de moradia, mesmo encravadas em área próxima ao centro comercial, ou foram refuncionalizadas, especialmente para serviços especializados (consultórios médicos-laboratoriais), função explicada pela proximidade com outra forma de função semelhante: o Hospital Rocha Faria. O hospital é um prédio baixo e, apesar de ter sido construído em terreno elevado, é pouco distinguível para os transeuntes mais desatentos da Avenida Cesário de Melo pela sua fachada estar coberta pela vegetação do seu jardim e sua entrada principal estar localizada na Rua Augusto de Vasconcelos, paralela a citada avenida. O muro feito com blocos de rocha é semelhante a outras construções comerciais e residenciais encontradas no bairro, um sinal, talvez, que seja característico e marque a data de sua construção por volta da década de 1930-1940.

Na Rua Olinda Ellis (antiga Estrada do Juary), o Hospital Joari foi praticamente reconstruído, contrapondo-se as formas mais antigas da paisagem que o rodeiam ao longo da via. Adquirido pela Rede D'or, ele foi renomeado como Oeste D'or tendo sua fachada radicalmente transformada em linhas arquitetônicas pós-modernas, que contrasta com as edificações do entorno que conservaram as feições tradicionais daquela paisagem, mesmo tendo, em alguns casos, suas funções alteradas. Esse recorte, que compreende as ruas Uruna, Guaraí, Augusto de Vasconcelos, Olinda Elis e Avenida Cesário de Melo guarda, possivelmente, as formas mais bem conservadas do passado do bairro. As ruas mais estreitas e muito sinuosas remetem ao padrão de produção português de arruamento identificado por Sérgio Buarque de Holanda. ${ }^{16}$ Percorrer esse traçado conscientemente buscando o passado é praticamente voltar a ele. Andar por essas vias, ignorando os carros modernos nas ruas e nas garagens e as placas de anúncio de serviços especializados, é possível para alguém sentir-se no Campo Grande da elite lusitana dos anos 1940-1950.

\footnotetext{
15 SANTOS, Milton. Espaço e Sociedade. Petrópolis, RJ: Vozes, 1980, p. 138.

${ }^{16}$ Cf.: HOLANDA, Sérgio Buarque. Raízes do Brasil. 26a ed. São Paulo: Companhia das Letras, 1995.
} 
Figura 8 - Hospital Rocha Faria, primeiro hospital de grande porte em Campo Grande, Rio de Janeiro na década de 1940.

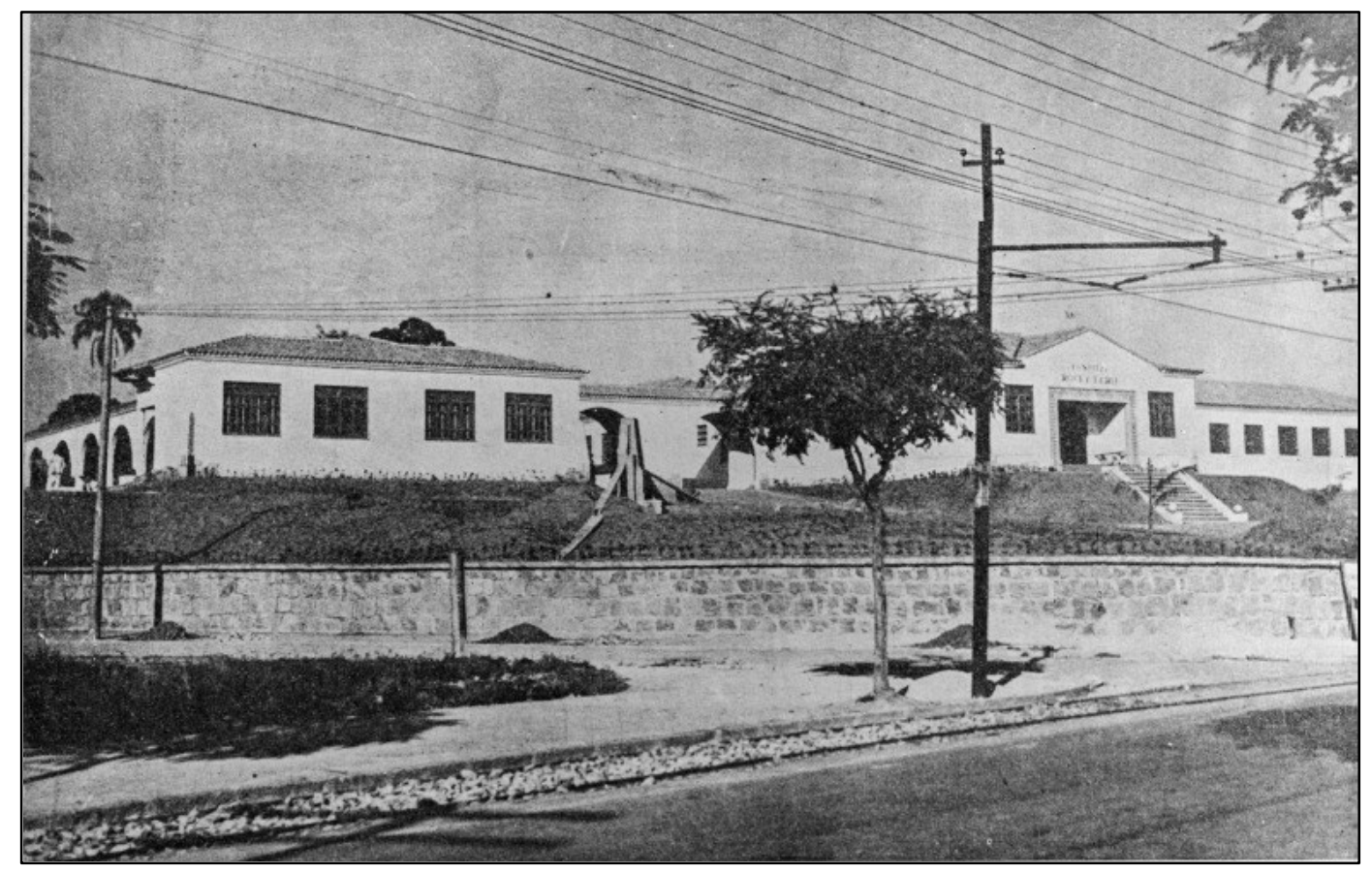

Fonte: ARQUIVO Nacional - Rio de Janeiro. Fundo Agência Nacional, Série Fotografias, Sub-série Eventos, doc. 7086. Fachada do Hospital Rocha Faria, Campo Grande, Rio de Janeiro, RJ. 1942. Negativo fotográfico, $9 \mathrm{~cm} ., \mathrm{p} \& b$. Disponível em:

http://sian.an.gov.br/sianex/consulta/Pesquisa_Livre_Painel_Resultado.asp?v_CodReferencia_id=148148 5\&v_aba=1. Acesso em: 20 fev. 2019.

No trecho da Avenida Cesário de Melo, que corta a ZCS1, as mesmas formas são encontradas, porém em menor número de edificações preservadas, que dividem a paisagem com objetos construídos em diferentes tempos, como agências bancárias e espaços educacionais (cursos de línguas, cursos preparatórios e campus de ensino superior, por exemplo).

Retornando a outro ponto do bairro, verificamos e podemos asseverar que as ruas lindeiras ao trilho do trem no centro de Campo Grande apresentam uma integração notável dos dois circuitos da economia urbana. Todo e qualquer espaço com fluxo de pedestres é ocupado por bancas de camelô, organizados precariamente no espaço e como parte do comércio informal, formando um corredor em frente aos pontos comerciais de marcas essencialmente locais do comércio formal. O interior dos trens é apinhado por vendedores ambulantes e o único espaço que não foi retomado por esses, ainda, é o interior dos ônibus, que na década de 1990 serviam como área de vendas antes do início de cada viagem. Os objetos construídos para a ligação entre os lados do bairro separados pela linha férrea servem como espaço comercial, também. A escadaria da estação ferroviária já abrigou lanchonetes e lojas de barbearia, ambulantes com venda de material de uso doméstico diverso e guloseimas. 
Figura 9 - Casas refuncionalizadas como consultórios médicos e laboratórios; serviços de imagem na Rua Uruna, Campo Grande - Rio de Janeiro.

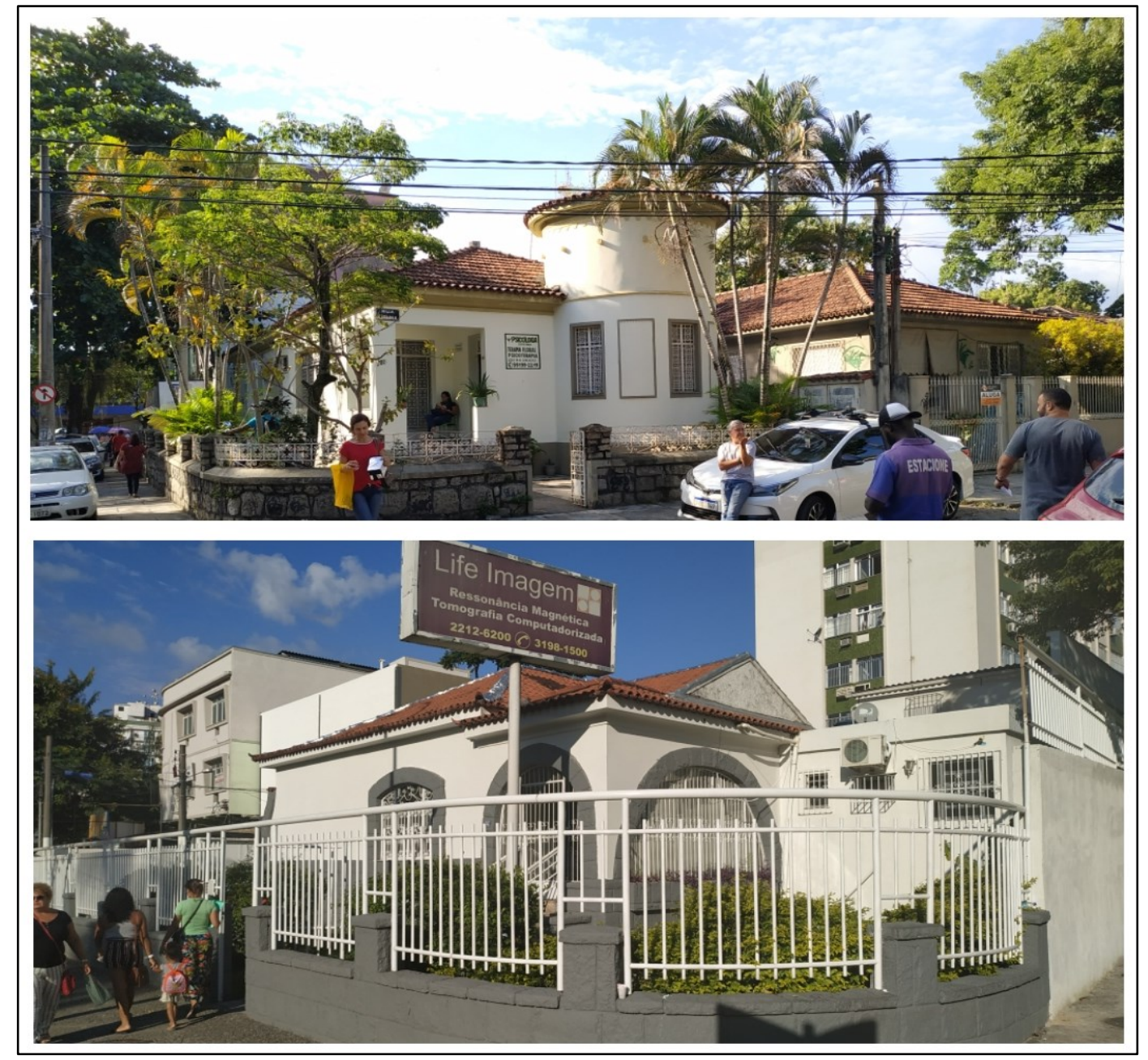

Fonte: BARATA, Paulo Henrique Araujo. O Sertão vira Calçadão... Op. cit., p. 48.

A passarela, que é conectada ao terminal rodoviário, é onde se vende os últimos lançamentos do cinema mundial e outros artigos proibidos como veneno de rato (popularmente conhecido como "chumbinho"), além de guloseimas em geral. O terminal rodoviário já foi tema de diversas reportagens sobre o seu estado de conservação, especialmente sobre a sua limpeza. Com muitos pontos comerciais de bares e restaurantes, além de stands de guloseimas, a manutenção nem sempre acompanhou a necessidade diária de limpeza. A calçada da linha ferroviária, na rua ao lado da rodoviária, é ponto de concentração de moradores de rua. Antes, o espaço abaixo da passarela era um espaço vazio conhecido pelos frequentadores do bairro pela infame e incômoda denominação "mijodrómo" pelo característico cheiro de urina devido ao péssimo uso do espaço público como latrina.

O ponto comercial mais notável na ligação "lado de cá" com o "lado de lá" é a passagem subterrânea, que os campograndenses chamam de "túnel" ou "buraco". Anteriormente, era ocupado por bancas comuns de madeira solta sobre uma base de ferro. 0 fluxo de pessoas parecia ser maior devido ao espaço exíguo que sobrava para a circulação. 0 
cheiro era extremamente desconfortável em épocas de calor, especialmente aqueles momentos chuvosos quando o sistema de captação transbordava. Os dejetos misturados a chuva afloravam cobrindo o piso da passagem subterrânea com filetes de água poluída e mal cheirosa. Após a reforma que o expandiu estabelecendo a ligação com a Rua Barcelos Domingos, e instalou um sistema de escadas rolantes conectando a passagem tanto a já citada rua como renovou o acesso à Praça Dr. Raul Boaventura, houve uma reorganização da exploração comercial da passagem subterrânea. Foram construídos boxes comerciais com ventilação feita a partir de aparelhos de ventiladores para aplacar o calor escorchante em certas épocas do ano e até um sistema de anúncio de TVs foi implantado.

O fluxo de consumidores em certos momentos do dia torna a passagem pelo túnel como alguma coisa a ser devidamente experienciada. A impressão inicial é a impossibilidade de atingir o outro lado, a saída do túnel, que levará o transeunte ao seu ponto de ônibus ou van. Indivíduos claustrofóbicos talvez tenham problemas em cruzar a passagem subterrânea nos seus momentos de pico. Às vezes o fluxo é impedido por compradores dos diversos produtos vendidos dentro do túnel, que ganhou a função de ponto comercial. Apesar de ser um dos maiores bairros em extensão territorial da cidade, o comércio adotou soluções japonesas de aproveitamento de espaço. Todo e qualquer ponto, como a parede externa de uma loja de roupas femininas ou a próprio "túnel", pode e será utilizado para o comércio de algum tipo de produto. As escadas do túnel são ocupadas por mais camelôs e, por vezes, pedintes que com seus bebês de colo passam parte do dia entre vender balas e gomas de mascar de baixo valor e pedir ajuda para a alimentação. A passagem tende a ser reveladora das relações sociais estabelecidas no espaço campograndense ao longo do tempo. 
Figura 10 - Inauguração da passagem subterrânea no bairro de Campo Grande, Rio de Janeiro, sem data definida.

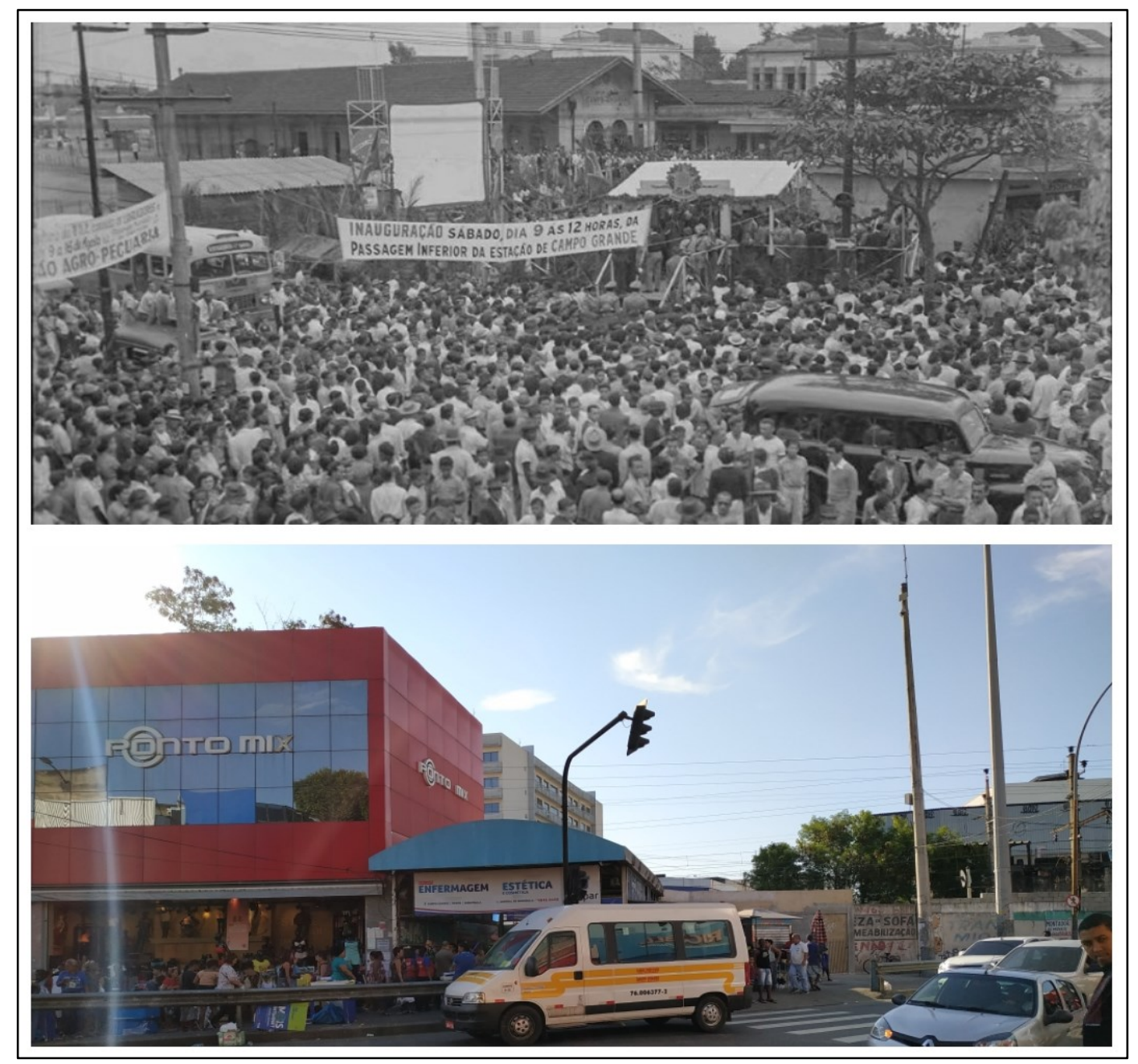

Fonte: ARQUIVO Nacional - Rio de Janeiro. Fundo Agência Nacional, Série Fotografias, Sub-série Eventos, doc. 6222. Inauguração da passagem inferior da Estação de Campo Grande, Estrada de Ferro Central do Brasil, Rio de Janeiro. Negativo Fotográfico, $9 \mathrm{~cm}$, p\&b. Disponível em:

http://sian.an.gov.br/sianex/Consulta/Pesquisa_Livre_Painel_Resultado.asp?v_CodReferencia_id=147923

8\&v_aba=1. Acesso em: 20 fev. 2019; BARATA, Paulo Henrique Araujo. O Sertão vira Calçadão... Op. cit., p. 157.

Ali, no túnel de Campo Grande, não se vende de tudo. Há dois tipos de produtos e serviços que dominam a oferta e procura: acessórios femininos / infantis e telefonia celular. Pelo menos a metade dos boxes oferece acessórios para o aparelho de celular: carregadores, cabos usb, suporte para celulares, capas, películas de proteção e até serviços de reparos feitos na hora. Não por acaso na "boca do túnel" do lado do Calçadão o grito de venda mais comum é "Chip da Tim!" ou de qualquer outra operadora que esteja usando a mão de obra precária para vender seus planos e produtos naquele momento. Não resta dúvida que a informalidade do comércio campograndense é alicerçada na taxa de natalidade da Zona Oeste, na demanda por acessórios femininos e nas necessidades e imperativos consumistas por comunicações modernas. 
Figura 11 - Área interna da passagem subterrânea e entrada pela Rua Ferreira Borges, Campo Grande.

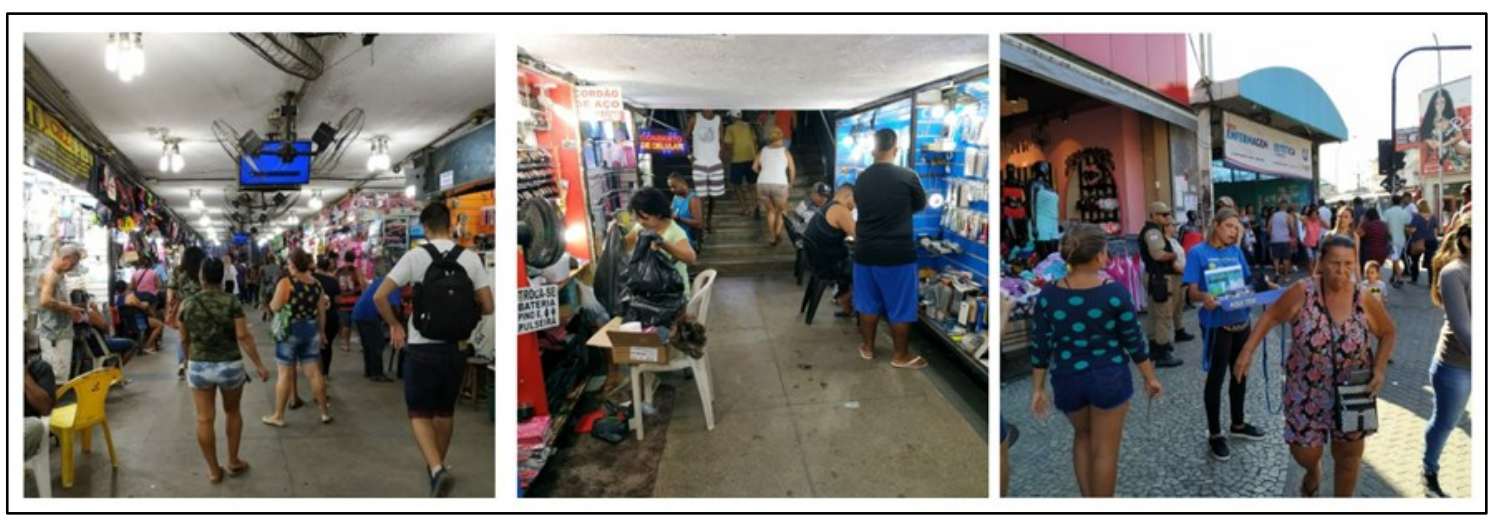

Fonte: BARATA, Paulo Henrique Araujo. O Sertão vira Calçadão... Op. cit., p. 50.

A citada operadora italiana tem um ponto de vendas do outro lado da rua, na entrada do Calçadão, e está em frente ao Moda Shopping, outro ponto de venda de acessórios e reparos para a telefonia celular. E esses pontos de venda de itens ligados a comunicação móvel tendem ao infinito. Difícil é não se deparar com anúncios de alguma operadora ou serviço disponível. Essa tão notável oferta de serviços ligados a comunicação celular no espaço comercial revela como um produto típico da revolução técnica-científica-informacional foi disseminado e popularizado. Compra-se o aparelho na loja, os acessórios no camelô, e, uma vez fora do prazo da garantia, faz-se o reparo na banca do técnico formado em eletrônica pela vida. É o acesso precarizado às novas tecnologias ofertadas pelo espaço ao cidadão comum.

O caminhar pelo Calçadão é uma mistura de cheiros, visões e, portanto, experiências sensoriais particulares para o indivíduo. A rua é livre da circulação de automóveis, como parte do plano inicial e cumprido até o presente momento. Em compensação o fluxo de pessoas pode ser exagerado em certos momentos do ano. De qualquer um dos pontos da rua, a visão da massa humana faz valer a expressão popular "mar de gente". O calçamento que mistura pedras portuguesas mal encaixadas e peças de concreto no piso desnivelado forma poças consideráveis em dias de chuva e certo desconforto ao andar em dias de sol. 
Figura 12 - Rua Coronel Agostinho, calçadão de Campo Grande, Rio de Janeiro por volta das 9h. da manhã de segunda-feira.

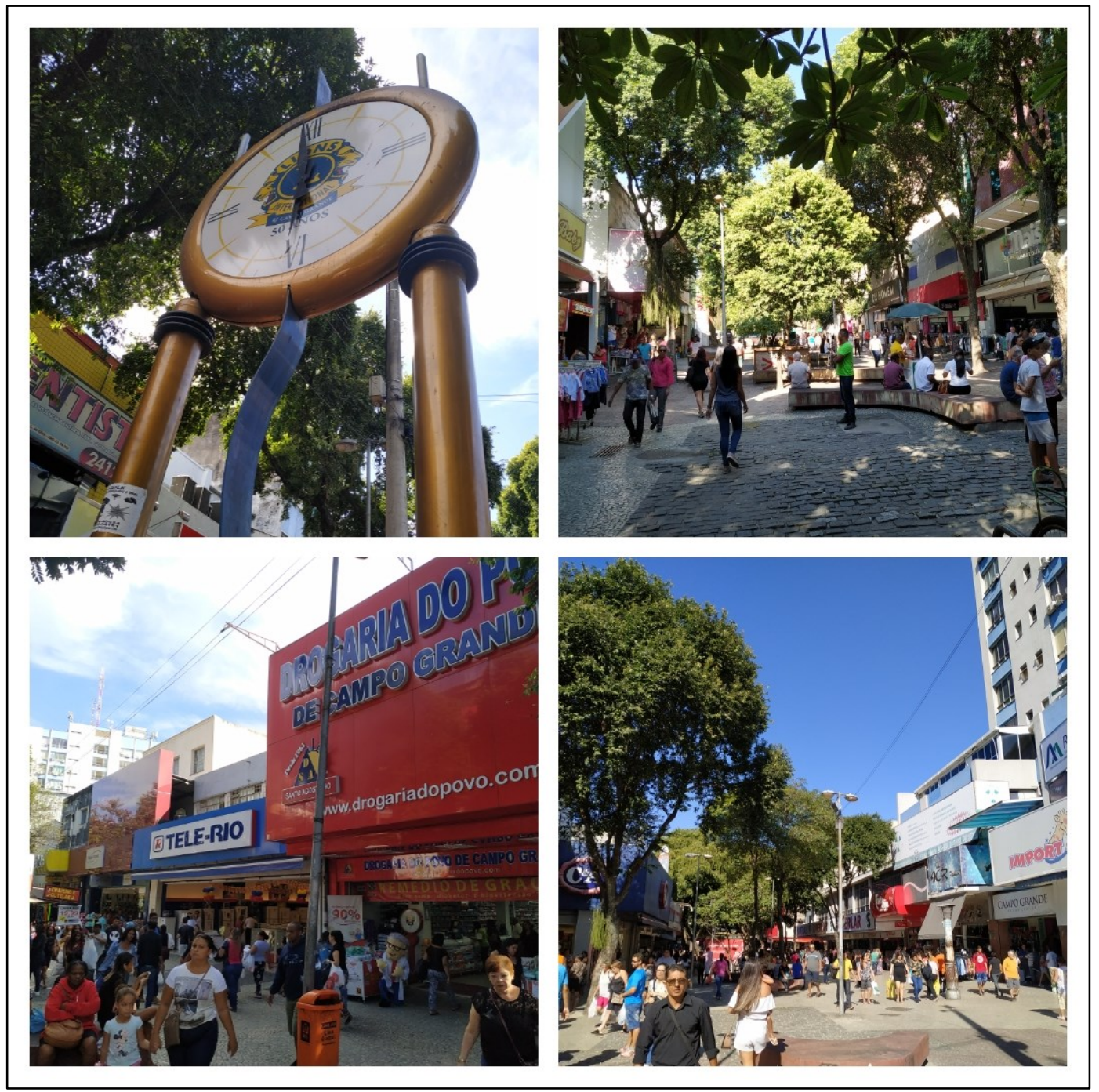

Fonte: BARATA, Paulo Henrique Araujo. O Sertão vira Calçadão... Op. cit., p. 52.

Durante muito tempo passar em frente ao Mercado São Braz, objeto comercial basilar para a formação do Calçadão, era sentir o cheiro da peixaria e de outros animais que eram vendidos nos estabelecimentos. Apesar de a peixaria continuar a existir, o cheiro de peixe e outros alimentos não é mais o predominante. Entretanto, para alguns moradores aquele cheiro característico permaneceu na memória olfativa relacionada aquele objeto comercial. O letreiro atual é mais condizente com as lojas a sua volta, que sobrecarregam a visão com placas brilhosas das mais diversas cores, tamanhos e tipos de fontes. Alguns letreiros são novos e muito bem cuidados, outras bloqueiam a visão da fachada original e alguns outros formam um conjunto nada harmonioso com as antigas e mal cuidadas fachadas que não conseguem esconder. A perda da memória e das antigas referências espaciais pela modificação da paisagem ocultando as antigas formas arquitetônicas para atender as necessidades de marketing e vendas, que transformam o objeto comercial em um produto a ser consumido, é 
um ônus do processo da produção do espaço. ${ }^{17} \mathrm{~A}$ perda da identidade é materializada na modificação dos objetos e a consequente padronização dessas formas que em conjunto tornam a paisagem indistinguível de qualquer outro ponto da cidade.

Infelizmente as construções antigas, belas, repletas de história, são modificadas com o tempo. Por vezes, são jogadas ao chão para uma arquitetura quadrada, sem curvas, muito parecida com uma caixa [...] A reforma acabou com as linhas cuidadosas da construção, trazendo apenas uma armação sem graça com propaganda de um comércio ordinário. ${ }^{18}$

Figura 13 - Forma arquitetônica original do prédio que abriga loja TIM na esquina da Rua Coronel Agostinho e Praça Raul Boaventura (antiga Praça 3 de maio).

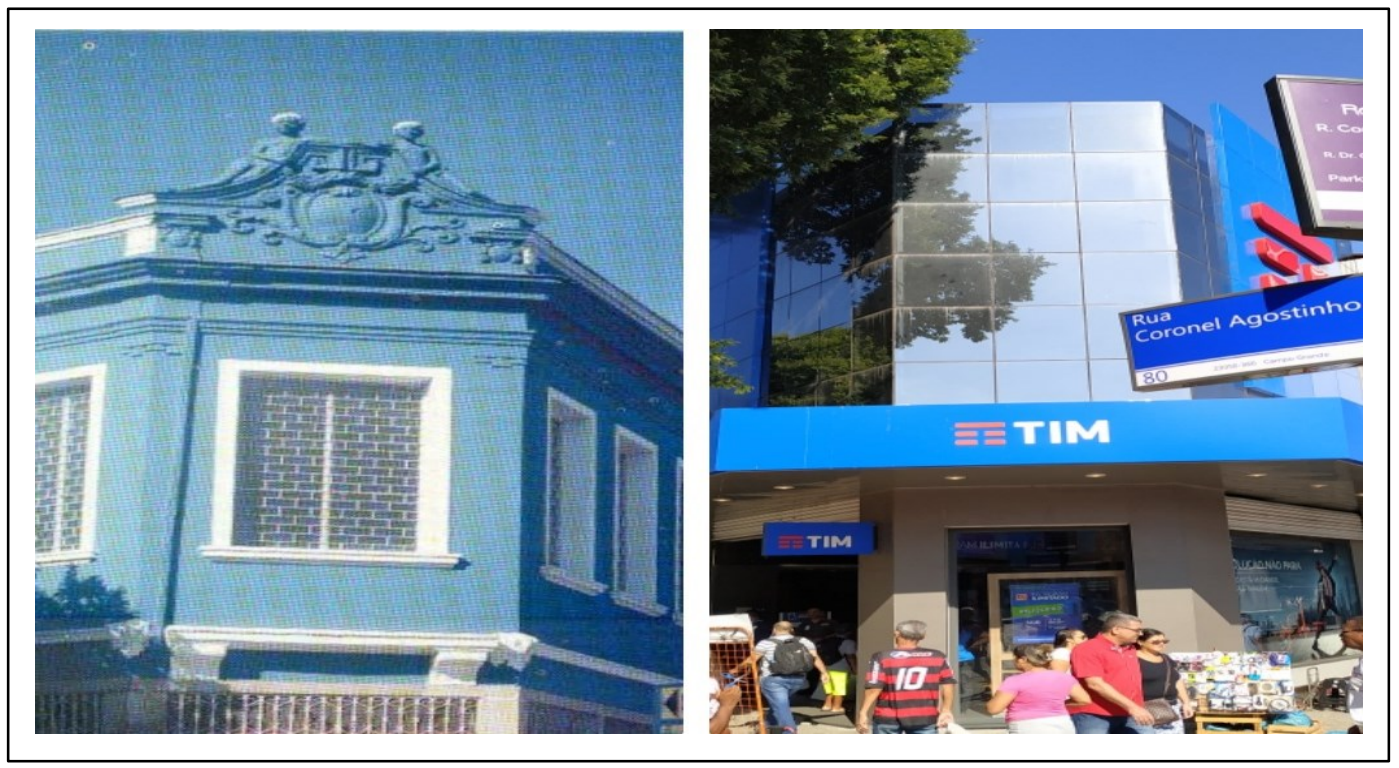

Fonte: MELO, Uilton Soares de. [s/d]. [Da série: Campo Grande das minhas lembranças...]. 2018. Facebook. (Plataforma Eletrônica). Disponível em:

https://www.facebook.com/photo.php?fbid=2404301746253713\&set=a.1101842733166294\&type=3\&th eater. Acesso em: 19 fev. 2019; Acervo Pessoal do Autor, 2019.

O Mercado São Brás ganha contornos semelhantes aos mercados tradicionais do século XXI. Como parte do processo de refuncionalização, abandona o aspecto de galpão destinado ao comércio de hortifrutti construído na década de 1960, pois a partir das últimas décadas do século XX expandiu suas atividades para outros fins comerciais.

\footnotetext{
17 PINTAUDI, Silvana. Anotações sobre o... Op. cit., p. 61. "Hoje, o lugar da compra, tal como a mercadoria a ser comprada, deve ser diferenciado, deve ter uma marca que o distingue de outros que contêm mercadorias que não seriam distinguidas e valorizadas se assim não fosse [...] Uma mercadoria que envolve outra, valorizando-a e conferindo distinção àqueles o frequentam". Idem. Grifo nosso.

${ }^{18}$ MELO, Uilton Soares de. [Da série: Campo Grande das minhas lembranças...]. Facebook. (Plataforma Eletrônica). 2018.2 Disponível em: https://www.facebook.com/photo.php?fbid=2404301746253713\&set=a.1101842733166294\&type=3\&th eater. Acesso em: 19 fev. 2019.
} 
Figura 14 - Antiga e atual fachada e ortografia do Mercado São Braz no bairro de Campo Grande, Rio de Janeiro.

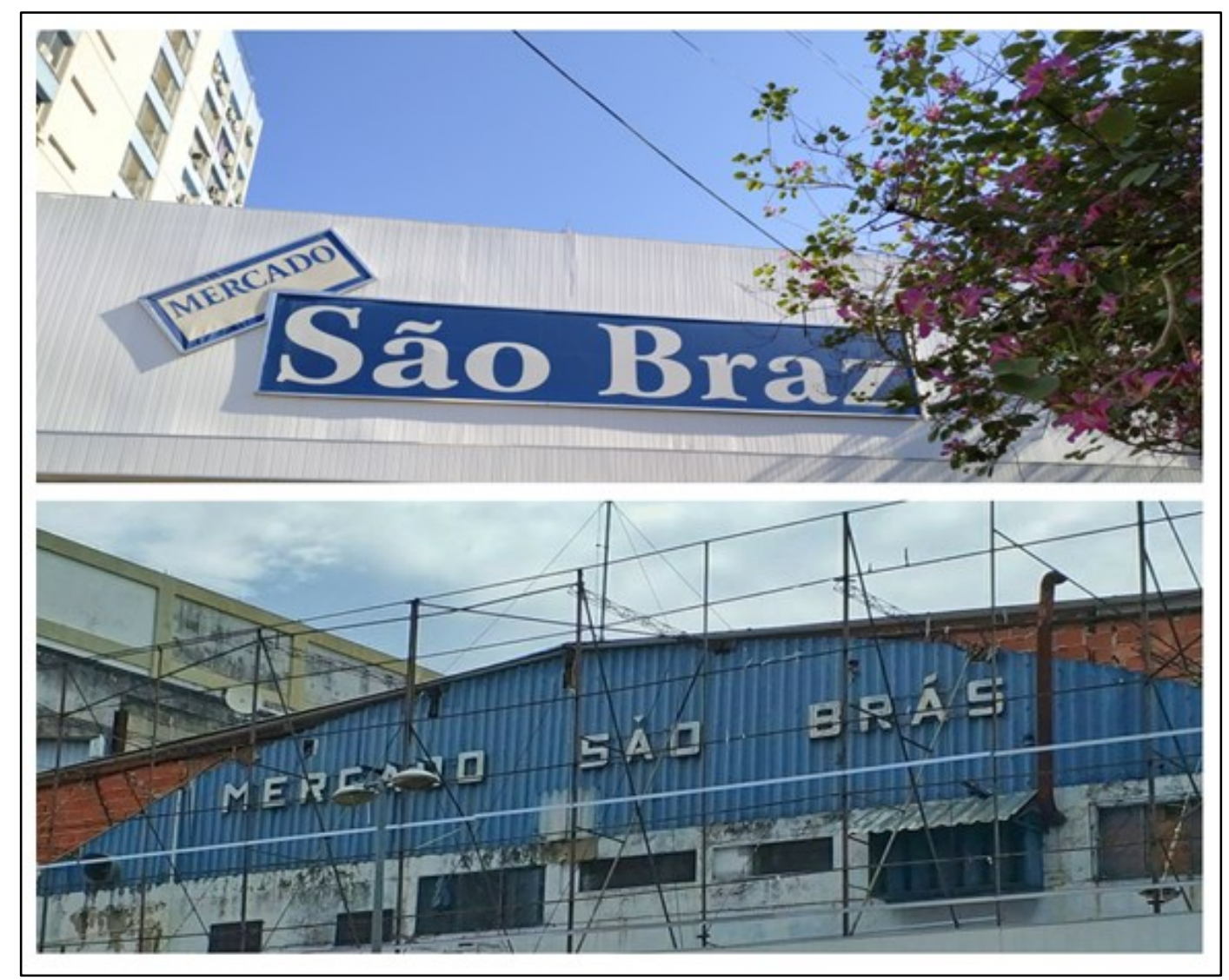

Fonte: Acervo Pessoal do Autor, 2019.

Em certo ponto da rua, em frente ao prédio Campo Grande Trade Center - o mais alto da rua e talvez o mais alto do bairro - há um ralo de esgoto que exala mau cheiro há anos. É algo tão característico daquele ponto que talvez os indivíduos já estejam habituados a não senti-lo ou a tê-lo como parte do ambiente. A partir de relatos de antigos moradores, por ali passa o Rio Campinho, que sem o plano de saneamento básico adequado recebe os dejetos das residências e comércio por todo o seu trajeto. Herança maldita do rápido movimento de expansão do bairro sem a devida adequação da infraestrutura urbana. No final da rua, próximo a Avenida Cesário de Melo, há uma leve subida tão pouco pronunciada que não é percebida por quem nela passa andando. Nesse ponto da rua não é incomum encontrar consumidores saindo de uma das lojas das Casas Bahia com seu televisor de altíssima definição de 49 polegadas nas mãos rumo ao ponto de ônibus na rodoviária. Em outras ocasiões os encontramos já no ponto do ônibus pedindo para que o motorista abra a porta traseira do veículo para facilitar o embarque do aparelho eletrônico. Aparelho de TV sendo carregado pelos seus compradores, senhoras carregadas de bolsas de compras das Lojas Americanas, Superlar, material escolar ou produtos para casa da TIDs, alunos das escolas ou passeando ou rumando aos pontos de ônibus, pais com os filhos no seu caminho para os consultórios médicos, panfletadores de cursos e serviços odontológicos e outros tipos são elementos essenciais e 
fazem parte da paisagem típica e memorável dessa rua comercial. O Calçadão continua sendo o Calçadão sem o fluxo de pedestres e consumidores? No caso do Calçadão, como negar que os fluxos são tão essenciais para a paisagem quanto os objetos que a compõem?

Ainda hoje existem interpretações díspares [...] a propósito da ideia de paisagem. [...] A esse respeito, basta lembrar ninguém menos que Milton Santos, em A Natureza do Espaço, avançou a interpretação segundo a qual a paisagem seria o espaço sem os homens... Compare essa posição, por exemplo, com aquela de Otto Schlütter, citado por Richard Hartshorne, para quem a paisagem necessariamente inclui os seres humanos (que são, no fim das contas, também entes perceptíveis). E o próprio Hartshorne, discutindo o conceito em questão, forneceu, por meio de exemplos dificilmente refutáveis, um argumento decisivo: seria razoável imaginar a Broadway sem ônibus, automóveis ou pessoas, ou o porto de Nova Iorque sem navios? ${ }^{19}$

Figura 15- Visão do Calçadão de Campo Grande a partir da Avenida Cesário de Melo, Rio de Janeiro em 2019.

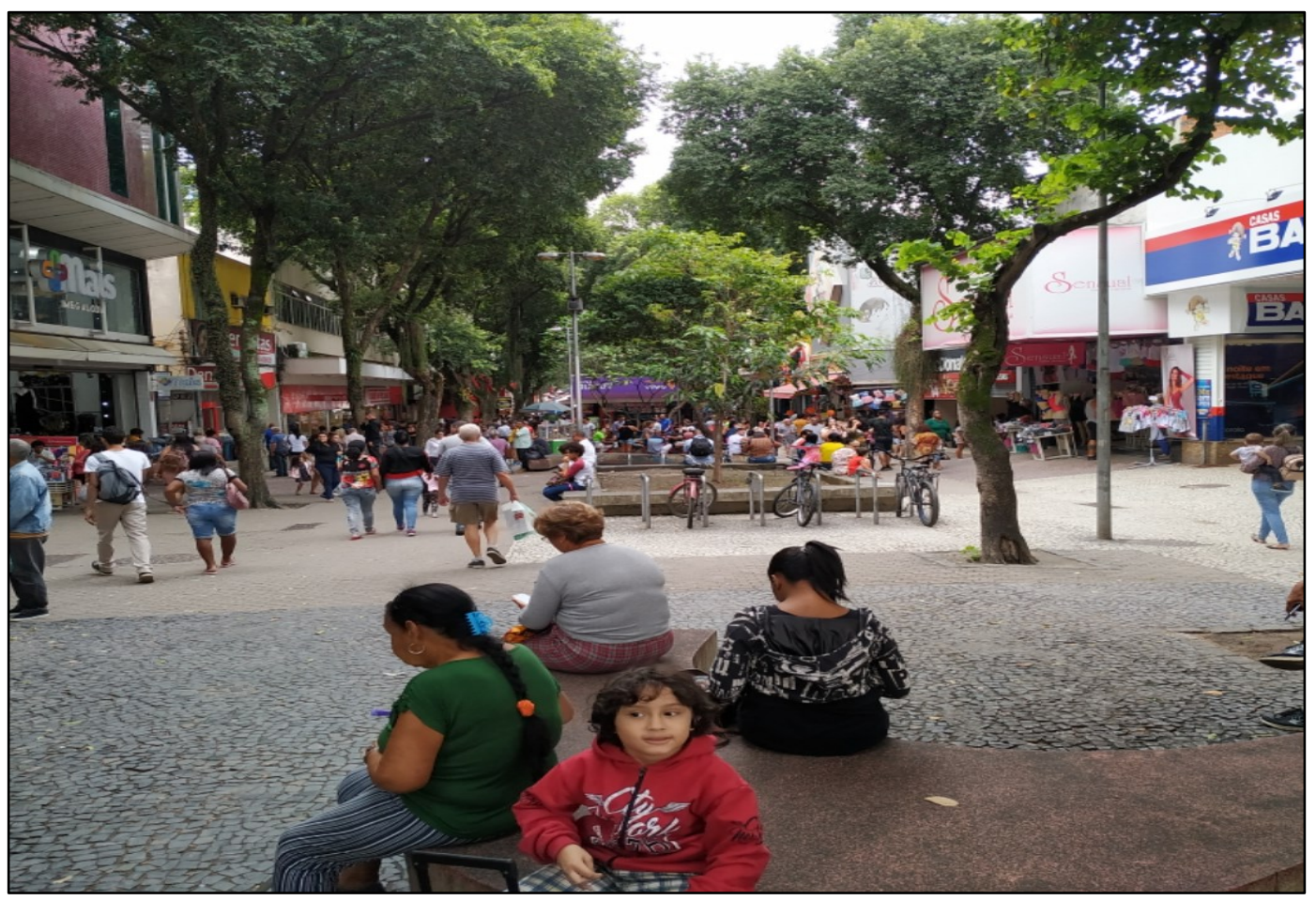

Fonte: BARATA, Paulo Henrique Araujo. O Sertão vira Calçadão... Op. cit., p. 219.

No Calçadão, há ruas e passagens menores, prováveis antigas vilas residenciais que ou servem como conexão entre as vias principais ou tornaram-se ruas sem saída, mas que foram ocupadas pelo uso comercial como a Travessa Dib, batizada com o nome da família que a ergueu como vila. Podemos estar influenciados pelo nome do logradouro, mas pode ser o mais próximo de uma rua comercial árabe na Zona Oeste do Rio de Janeiro. É uma rua estreita e

19 SOUZA, Marcelo Lopes de. Os conceitos fundamentais da pesquisa sócio-espacial. Rio de Janeiro: Bertrand Brasil, 2013, p. 59-60. 
sinuosa que liga a Rua Coronel Agostinho a Rua Doutor Caetano Faria e Castro. Seu calçamento de paralelepípedos é encontrado somente em outra rua: a Rua Viúva Dantas. A calçada estreita demais, de um lado, e ocupada pelas bancas e placas das lojas, do outro, força que caminhemos pela rua. Não há nenhum receio, pois lembramos que a circulação de veículos motorizados não é permitida.

Figura 16 - Vista da Travessa Dib a partir da Rua Coronel Agostinho em Campo Grande, Rio de Janeiro em 2019.

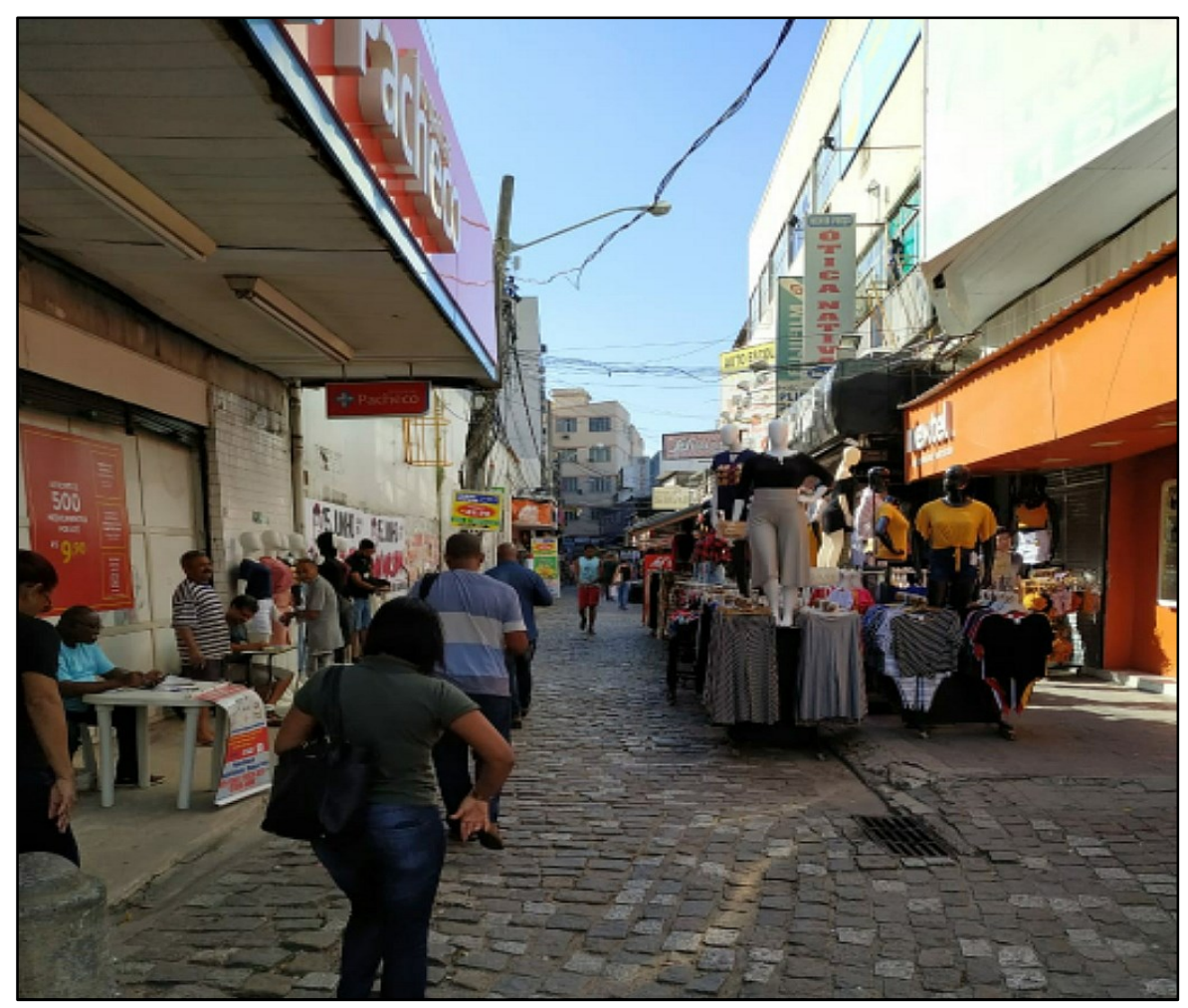

Fonte: BARATA, Paulo Henrique Araujo. O Sertão vira Calçadão... Op. cit., p. 55.

A rua torna-se estreita demais para que três pessoas contornem a curva que desemboca na Rua José Ferreira, lateral ao Passeio Shopping, e Rua Doutor Caetano Faria e Castro. Enquanto a última é uma rua estritamente comercial com prédios comerciais, como o Edifício Estrela, a primeira apresenta uma ocupação residencial com os prédios de um condomínio em pleno núcleo da Zona Comercial. Ao chegarmos na esquina da José Ferreira com a Viúva Dantas, a rua de paralelepípedos com calçadas de boa largura de ambos os lados nos faz esquecer que é uma área de passagem de veículos. A fachada de uma das entradas do Passeio Shopping, dando acesso à loja âncora C\&A, mais a arborização da rua forma uma combinação singular no centro do bairro. O adensamento comercial é grande, o fluxo de pessoas é intenso, mas a combinação dos elementos é diferente do restante das ruas do núcleo comercial do bairro. Talvez o calçamento de paralelepípedos remeta a uma paisagem de cidade interiorana. E essa percepção pode não ser totalmente equivocada, pois o 
logradouro já foi residencial. Do antigo endereço do Clube dos Aliados, atualmente na Estrada do Mendanha, sobrou o prédio com o seu letreiro, que já fez algumas crianças questionarem suas mães sobre o porquê daquela edificação ter o nome do referido clube na sua fachada. Próximo da esquina da Viúva Dantas com a Aurélio de Figueiredo localiza-se de um lado uma outra entrada do Passeio Shopping, pela loja Ricardo Eletro, e na outra calçada o Audi Shopping.

A Rua Aurélio de Figueiredo ou rua da Rodoviária poderia ser chamada de rua do Guanabara, também. Antigo caminho do bonde, a rua é bem ampla nas proximidades com a Avenida Cesário de Melo devido à existência de uma faixa de rolamento a mais, que se estende até a Rua Doutor Caetano Faria e Castro. O comércio é menos denso, com menor número de marcas famosas. É formada por bares, lanchonetes e terrenos ainda a serem explorados como o estacionamento construído no terreno antes parcialmente ocupado por uma residência de propriedade dos herdeiros de uma antiga família produtora de laranja e outro que serve como ponto final de vans do transporte alternativo. Por ser acesso à rodoviária de Campo Grande, a visão que se tem no cair da tarde é de lanternas vermelhas e laranjas dos veículos que tornam o trânsito quase que impossível de ser vencido. As vans fazem ponto na esquina da loja Renner, tornando a circulação ainda pior, uma vez que logo a frente o fluxo dessa rua encontra-se com o fluxo da Rua Xavier Marques na Rua Ferreira Borges fazendo o nó na circulação viária do centro de Campo Grande. Seguindo em diante, retornamos a entrada da passagem subterrânea em frente a Rua Coronel Agostinho e da Praça Dr. Raul Boaventura.

A reforma da passagem subterrânea melhorou a conexão dos pedestres entre os dois lados do bairro, transformando a própria passagem numa continuidade da rua comercial ao integrar o Calçadão diretamente a Rua Barcelos Domingos, que foi fechada para o tráfego de carros, também. A Barcelos Domingos, a do "boca do túnel" do "lado de lá" é mais moderna com cobertura de metal e mais ampla permitindo a melhor circulação dos pedestres. Ao sair do "buraco" deparamo-nos com pontos comerciais de vestuário, utensílios domésticos, supermercados e as onipresentes agências bancárias, além de outros tipos comerciais. Há uma estátua em homenagem a um compositor do bairro, Adelino Moreira, evocando a construção e manutenção da memória do bairro pela implantação de símbolos que permitam ao morador a constante recordação da História.

Quando um período deixa de interessar ao período seguinte, isso não quer dizer
que o grupo se esqueceu de uma parte do passado. O que acontece é que, na
realidade, o grupo já não é mais o mesmo. Quando isso ocorre, e se não quer se
perder uma lembrança que não mais se sustenta por si mesma na consciência
do grupo, é comum então que essa lembrança seja eternizada, que seja
registrada, transformando-se então em memória histórica.

O cheiro de comida e gordura é facilmente sentido devido à quantidade de barracas voltadas para lanches: pizzas, cachorro quente, sanduíches, churrasco no espeto (o famoso "churrasquinho de gato") disputam clientes com as lanchonetes, bares e restaurantes do tipo

${ }^{20}$ ABREU, Maurício de. A evolução urbana do Rio de Janeiro. Rio de Janeiro: Prefeitura da Cidade do Rio de Janeiro, 2008, p. 26. 
autosserviço presentes na rua. A visão de uma filial do Senac (Serviço Nacional de Aprendizagem Comercial) não nos permite esquecer do peso do comércio para o bairro e o peso do comércio do bairro para a arrecadação da cidade. Destaca-se a verticalização, ainda que deveras modesta, do espaço construído com a presença de prédios comerciais e residenciais cercados por construções baixas de pavimento único. Novamente, as fachadas dessas construções e, por conseguinte, a história que contam são negadas pelo uso dos letreiros que o comércio utiliza atualmente. Era costume gravar a data da construção da edificação no topo da fachada. Assim, conseguimos identificar um sobrado datado de 1950 e uma construção de único pavimento de 1926, no qual funciona uma franquia das Lojas Americanas. Há outras edificações antigas cujo precário estado de conservação não nos permite identificar com precisão a data de inauguração.

Em outro momento tornou-se comum o uso de azulejos com gravuras alusivas às santidades e divindades católicas. A recorrência desse tipo de adorno na fachada das casas campograndenses funciona como identificador da massiva influência da religião e, por conseguinte, da Igreja na formação das dimensões social e cultural, por exemplo, e seus rebatimentos espaciais no espaço do bairro. São evidências da empiricização do tempo no espaço, pois é o conjunto de agentes e atores hegemônicos e anti-hegemônicos que constroem e gravam suas marcas no espaço. ${ }^{21}$ Devido às mudanças dos padrões arquitetônicos, não é suficiente observar o sumiço desse tipo de decoração das fachadas para atestar a decadência do poder da Igreja Católica no bairro. Mesmo que tenham surgido templos das igrejas neopentecostais pelo centro do bairro, como a Igreja Assembleia de Deus na Avenida Cesário de Melo. O caso mais emblemático foi o fim do Cine Palácio, que hoje funciona como mais um templo religioso da Igreja Universal do Reino de Deus.

${ }^{21}$ SANTOS, Milton. A Natureza do Espaço... Op. cit. 
Figura 17 - Casario refuncionalizado na Rua Barcelos Domingos, Campo Grande - Rio de Janeiro em 2019.

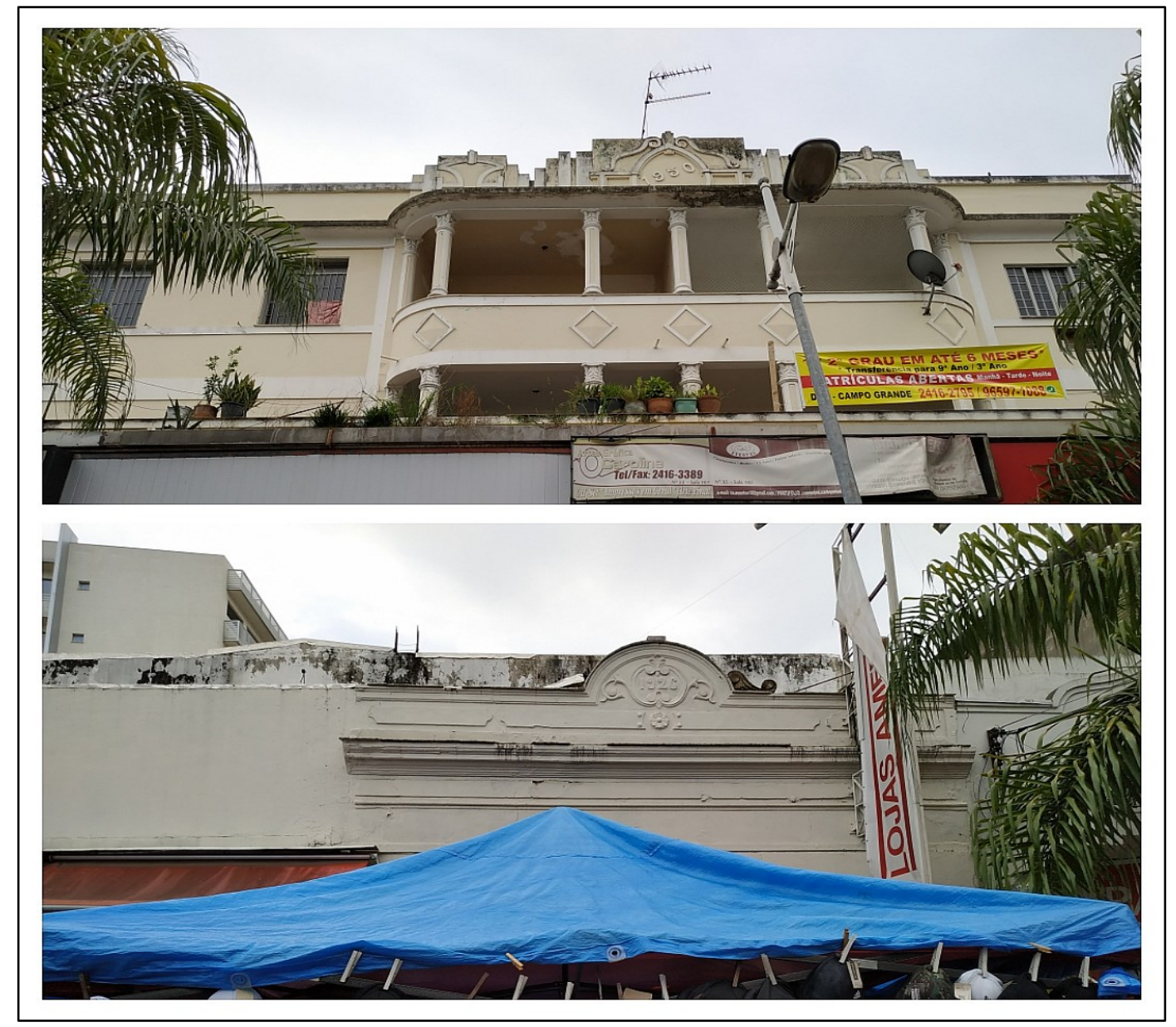

Fonte: BARATA, Paulo Henrique Araujo. O Sertão vira Calçadão... Op. cit. , p. 57.

As ruas transversais a Barcelos Domingos, como a Rua Aracaju e Alfredo de Morais, possuem casario antigo preservado e em parte refuncionalizado. Na Alfredo de Morais há uma residência que guarda a memória e é herança das vilas residenciais existentes: a Villa Santo Antônio. Algumas casas parecem saídas do túnel do tempo tamanho o estado de conservação com a fachada coberta de azulejos da época da sua construção.

O mesmo ocorre na Rua Jaguaruna, na qual o Hospital Nossa Senhora do Carmo promoveu uma quase área de coesão de serviços médico-hospitalares ao utilizar as antigas casas como parte do complexo hospitalar atraindo outros serviços médicos no seu entorno imediato. Entretanto, o entorno continua sendo uma área com grande densidade residencial. Esse fator talvez explique o razoável número de instituições de ensino público e privado de educação básica existentes nessa porção do logradouro campograndense. 
Figura 18 - Casario refuncionalizado para serviços médico-hospitalares na Rua Jaguaruna, Campo Grande, Rio de Janeiro.

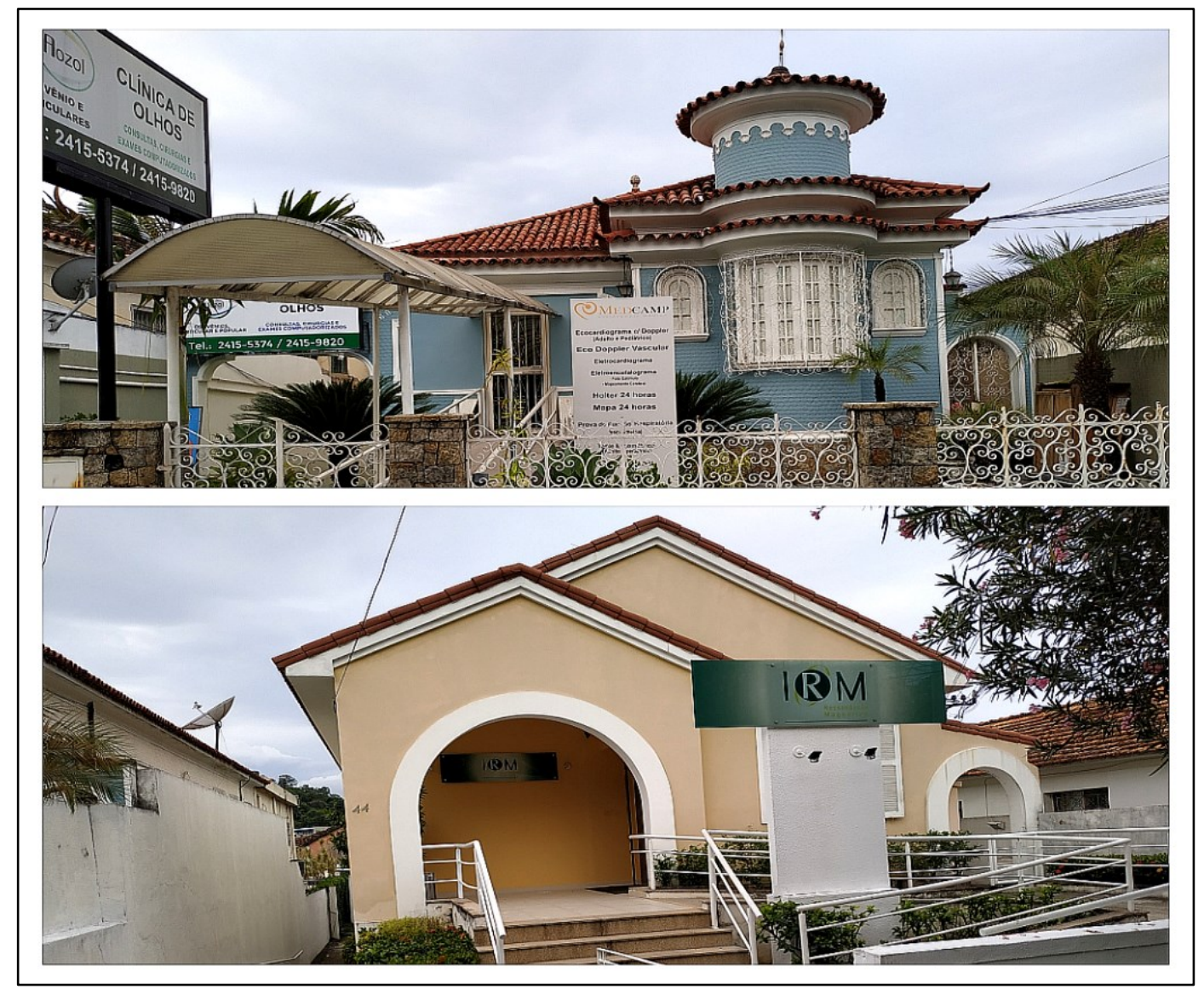

Fonte: BARATA, Paulo Henrique Araujo. O Sertão vira Calçadão, Op. cit., p. 58.

Nas ruas Gianerini, Albertina, Vítor Alves, Domingos do Couto, Ivo do Prado e Tenente Ronald Santoro, que se sucedem da mais próxima para a mais distante da Rua Barcelos Domingos, a densidade comercial decai conforme a distância aumenta da última rua citada. Há inúmeras residências antigas e algumas remanescentes de antigas vilas residenciais extintas. Não parece o mesmo bairro de algumas centenas de metros atrás. Nada é ouvido sobre itinerários de vans gritados pelos cobradores, há uma ausência de músicas pré-gravadas sendo tocadas por caixas de som anunciando ofertas, o som dos motores dos mais diversos meios de transporte terrestres não é algo incômodo aos ouvidos, perturbando os pensamentos dos transeuntes. A sensação de estar em uma cidade interiorana deve ser aquele sentimento tão saudosamente declarado pelos antigos moradores. Pode ser que essas características expliquem a impressão que os moradores das ruas mencionadas são basicamente antigos moradores do bairro, fato confirmado pelo morador Luís Carlos. 
Figura 19 - Casa azul da Villa São José, datada de 1928, na Rua Vítor Alves e casa verde da Villa Aurora, datada de 1929, na Rua Barcelos Domingos, Campo Grande - Rio de Janeiro.

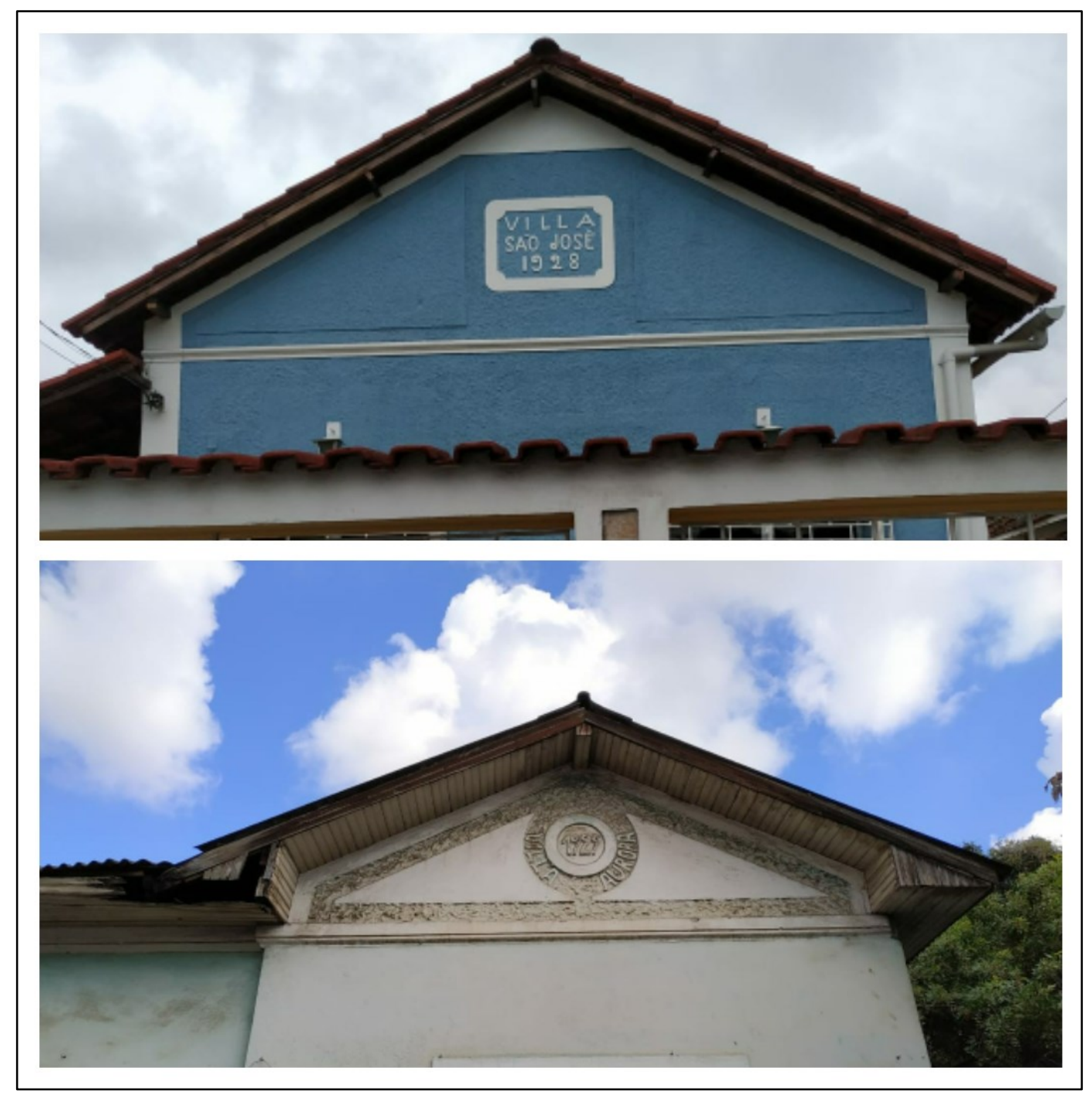

Fonte: BARATA, Paulo Henrique Araujo. O Sertão vira Calçadão... Op. cit., p. 59.

Os terrenos são grandes quando comparados aos atuais ofertados pelo mercado. 0 padrão arquitetônico das residências foi nada ou pouco alterado. Até mesmo as janelas originais foram mantidas, com acréscimo de grades como artifício para aumentar a sensação de segurança. A grande incoerência é a manutenção de muros extremamente baixos, mas que conferem a essas ruas uma paisagem muito próxima ao que possivelmente eram à época da produção inicial desse espaço. É notável o menor refinamento das linhas arquitetônicas e imponência do casario quando comparados àquelas do entorno da Igreja Matriz do Desterro. 
Figura 20 - Vila Dona Ruth e casas na Rua Domingos do Couto, Campo Grande - Rio de Janeiro.

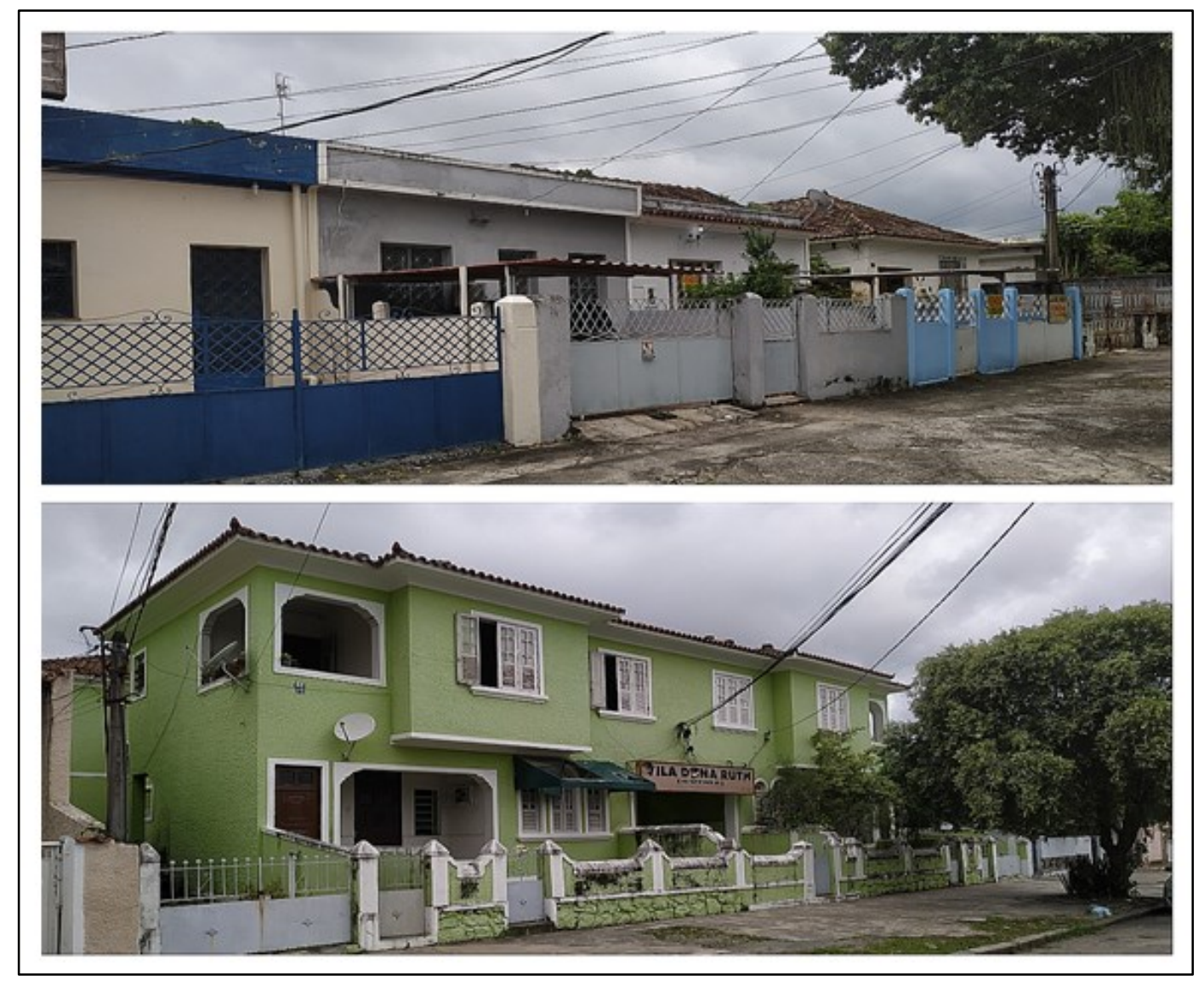

Fonte: BARATA, Paulo Henrique Araujo. O Sertão vira Calçadão... Op. cit., p. 60.

O transeunte andando por essa paisagem com tantos elementos de um passado cada vez mais conjugado no pretérito é rapidamente resgatado a 2019 pela visão do prédio de arquitetura pós-moderno batizado de "West Medical Center" que se impõe com 8 pavimentos na Rua Ivo do Prado. Devido ao casario baixo, esse prédio comercial, voltado para os serviços médicos, pode vir a se tornar uma referência espacial do lado norte da ZCS2, um objeto de grande visibilidade na paisagem. É um objeto pós-moderno com a sua fachada espelhada e de concreto pré-armado em cor mais próxima ao natural. O elevador panorâmico do prédio não revela muito mais sobre a paisagem do que já pode ser visto em outros pontos do bairro. Os serviços e a estrutura interna do prédio em nada lembram ou remetem ao subúrbio pobre, precarizado e abandonado descrito pela obra de Lima Barreto. A decoração do seu interior é similar a prédios comerciais modernos. Mais uma vez, tem-se a impressão, baseado no que já ocorreu em outro ponto do bairro, que o prédio comercial é um monstro pós-moderno prestes a solapar as casas de um tempo cada vez mais distante no espaço campograndense. 
Figura 21 - Fachada do West Medical Center na Rua Ivo do Prado e casas na testada da Rua Campo Grande com o prédio West Medical Center ao fundo

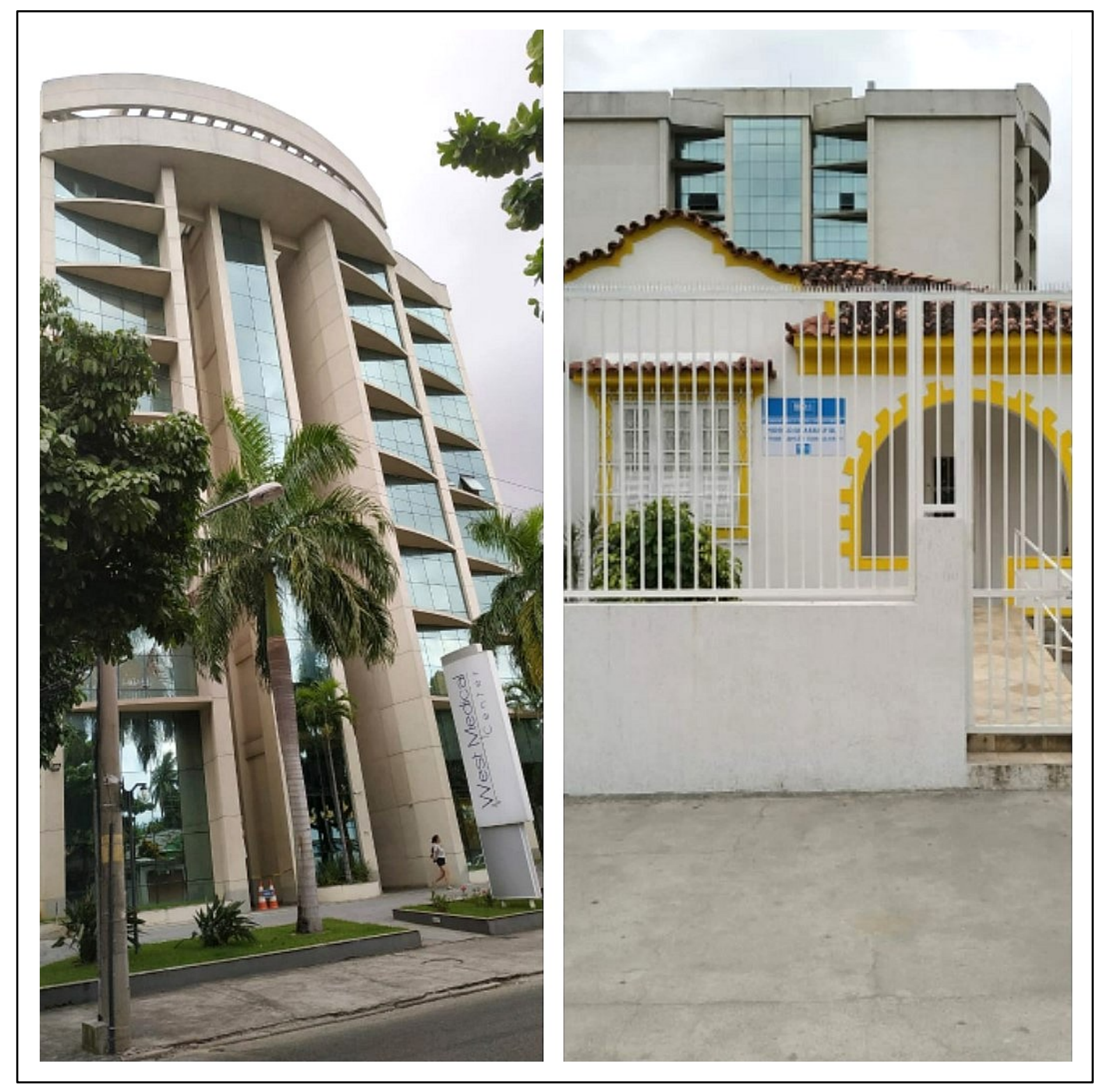

Fonte: BARATA, Paulo Henrique Araujo. O Sertão vira Calçadão... Op. cit., p. 61.

Caminhando para o oeste, ao subir a passarela da linha ferroviária, o marco referencial para dividir o bairro em norte e sul, estamos quase no limite da ZCS2, próxima a Rua Madre Teresa, com visão privilegiada da área com maior densidade de verticalização do bairro, que compreende porções da ZCS2 e ZR4 tanto com prédios comerciais quanto prédios residenciais. Caso o transeunte decida seguir o caminho de pedestres pelo Viaduto Alim Pedro a visão é ainda mais reveladora da concentração de prédios no recorte. Os principais prédios comerciais construídos no século XXI estão nesses pontos de contato entre a ZCS1 e a ZCS2 estabelecidos em áreas próximas a Estrada do Monteiro, o caminho que leva para Guaratiba e Barra da Tijuca. Para o pesquisador que precise estabelecer marcos de referência espacial para a limitação das zonas comerciais, essas construções funcionam perfeitamente para esse propósito.

O acúmulo de tempos na paisagem e no espaço não pode ser ignorado. Os "monstros" pós-modernos, materializados como prédios de fachadas espelhadas, em conjunto com os 
novos prédios residenciais se impõem no horizonte. Mais do que um prelúdio do que está por vir, são símbolos do que alguns podem classificar como a continuidade do desenvolvimento do bairro. "Desenvolvimentos e dos bons!", como já foi definido pela administradora regional Elza Osborne em outro momento no passado. ${ }^{22}$ As suas fachadas servem não para refletir o passado materializado no casario que fez Campo Grande ser o que é, mas como faróis que refletem a luz do Sol, que iluminam possíveis novos caminhos abertos e liderados por novos (e velhos) agentes que produzem o (novo) espaço do bairro.

Edifícios com quatro ou mais pavimentos estão localizados nas ruas Viúva Dantas, Coronel Agostinho, Agostinho Coelho e Dr. Caetano Faria e Castro. Esse tipo de prédios comerciais são predominantemente ocupados por serviços especializados (médicos). Os objetos de dois pavimentos, que predominam na paisagem do centro do bairro, são geralmente utilizados pelo comércio, que utiliza o segundo andar como seu depósito de produtos. Percebemos que as ruas centrais da ZCS1 são aquelas com maior verticalização, adensamento terciário e presença de franquias. Conforme nos movemos para as ruas exteriores a essa zona, como as ruas Cândido Magalhães, Amaral Costa e Xavier Marques, o inverso é notado devido a uma menor verticalização dos objetos e a ausência de franquias.

O reconhecimento do centro a pé, ao mesmo tempo em que realizamos o levantamento fotográfico, permitiu perceber algo relevante: não importa o ponto que miramos para fotografar, sempre aparecerá uma agência bancária no plano. Os frequentadores do bairro costumam chamar as ruas não pelos seus nomes, mas pela referência da função exercida por determinado objeto localizada naquela rua ou pelo apelido popular. A Rua Coronel Agostinho é o Calçadão, a Aurélio Figueiredo é a rua da rodoviária e a Augusto de Vasconcelos é a rua do Banerj, para os mais antigos, rua do Bradesco ou Unibanco, pois varia dependendo em qual instituição o indivíduo é correntista, ou simplesmente de rua dos bancos. ${ }^{23}$ No passado, a Augusto Vasconcelos concentrava essas três instituições bancárias distintas e, por consequência, a maioria das agências do bairro. Em rua paralela, Rua Augusto Coelho, havia uma agência do banco Bamerindus, posteriormente HSBC e atual Santander. As outras duas eram os bancos públicos: o Banco do Brasil literalmente virando a esquina na Rua Amaral Costa e a Caixa Econômica Federal na Avenida Cesário de Melo, próximo ao Hospital Rocha Faria. A multiplicação das agências extrapolou essa rua e até mesmo o centro do bairro.

\footnotetext{
${ }^{22}$ Referente à fala de Elza Osborne proferida na reportagem "Campo Grande - Capital do Sertão": "Aqui está sendo erguida uma nova metrópole; para aqui estão vindo as grandes lojas comerciais, para aqui virão as grandes indústrias. Ali, no centro, é que não podem existir granjas. Isso, meu filho, é desenvolvimento, e do bom". Correio da Manhã, Rio de Janeiro, 12 jan. 1970, Caderno Grandes Reportagens, p. 5.

23 BANERJ é o antigo Banco do Estado do Rio de Janeiro, que foi privatizado e incorporado à instituição financeira Itaú. Atualmente o Unibanco se encontra igualmente fundida ao Itaú.
} 
Figura 22 - Agências dos bancos Bradesco e Itaú na Rua Augusto de Vasconcelos, Campo Grande - Rio de Janeiro

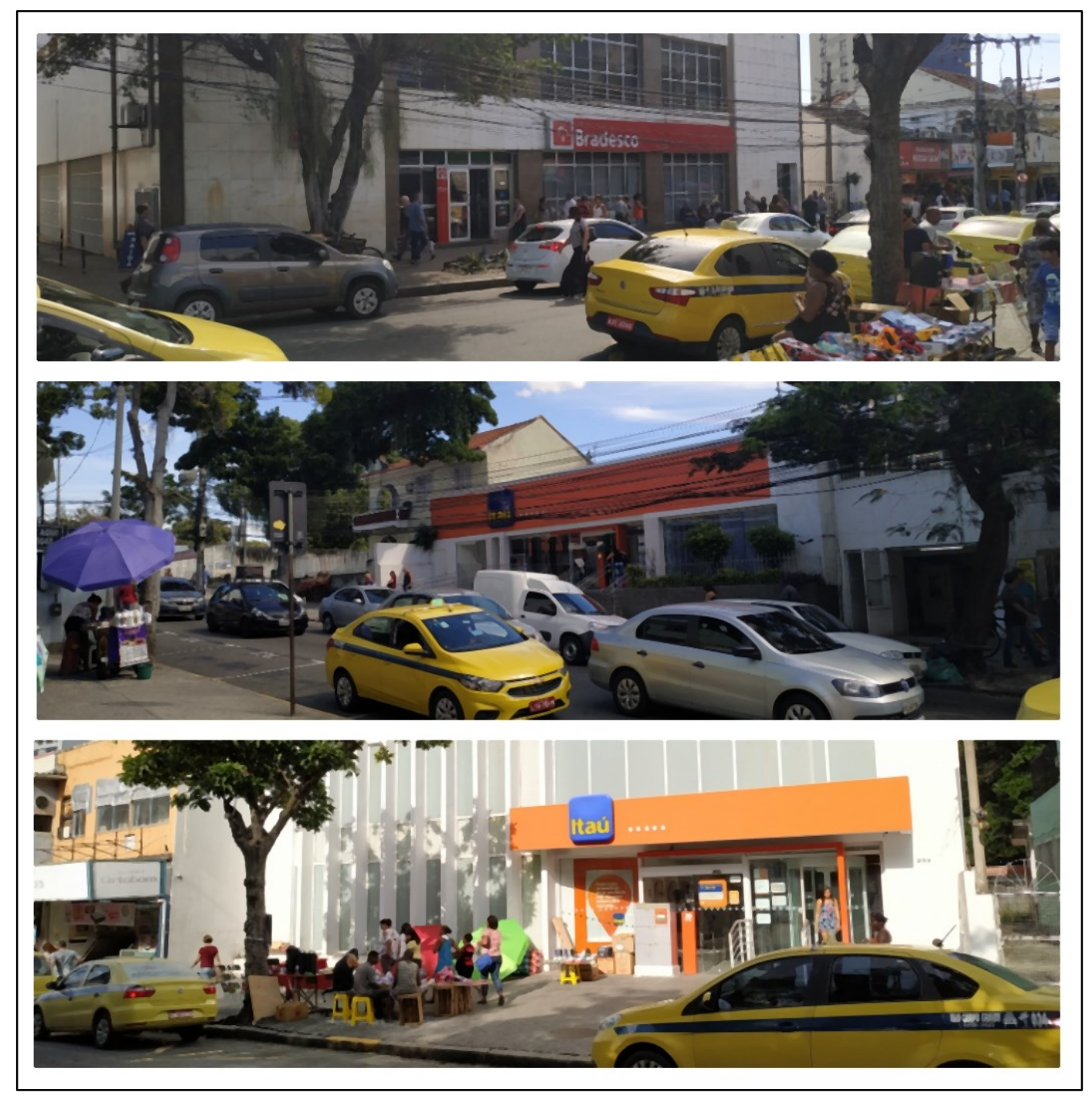

Fonte: BARATA, Paulo Henrique Araujo. O Sertão vira Calçadão... Op. cit., p. 63.

A pequena Rua Agostinho Coelho, que é esquina com a Augusto Vasconcelos, possui três outras agências, a Rua Viúva Dantas, Aurélio de Figueiredo e Barcelos Domingos e a Avenida Cesário de Melo todas no centro do bairro são endereços de uma agência, pelo menos. E quase sempre endereço de duas ou mais de duas agências, pelo menos. $O$ sucesso do bairro como centro comercial pode ser medido pela profusão de tais agências bancárias espalhadas pelo centro e para além do centro do bairro. 
Figura 23 - Esquina das ruas Engenheiro Trindade e Agostinho Coelho e suas agências bancárias: Santander no primeiro plano, Bradesco à esquerda e Itaú coberto pelas palmeiras.

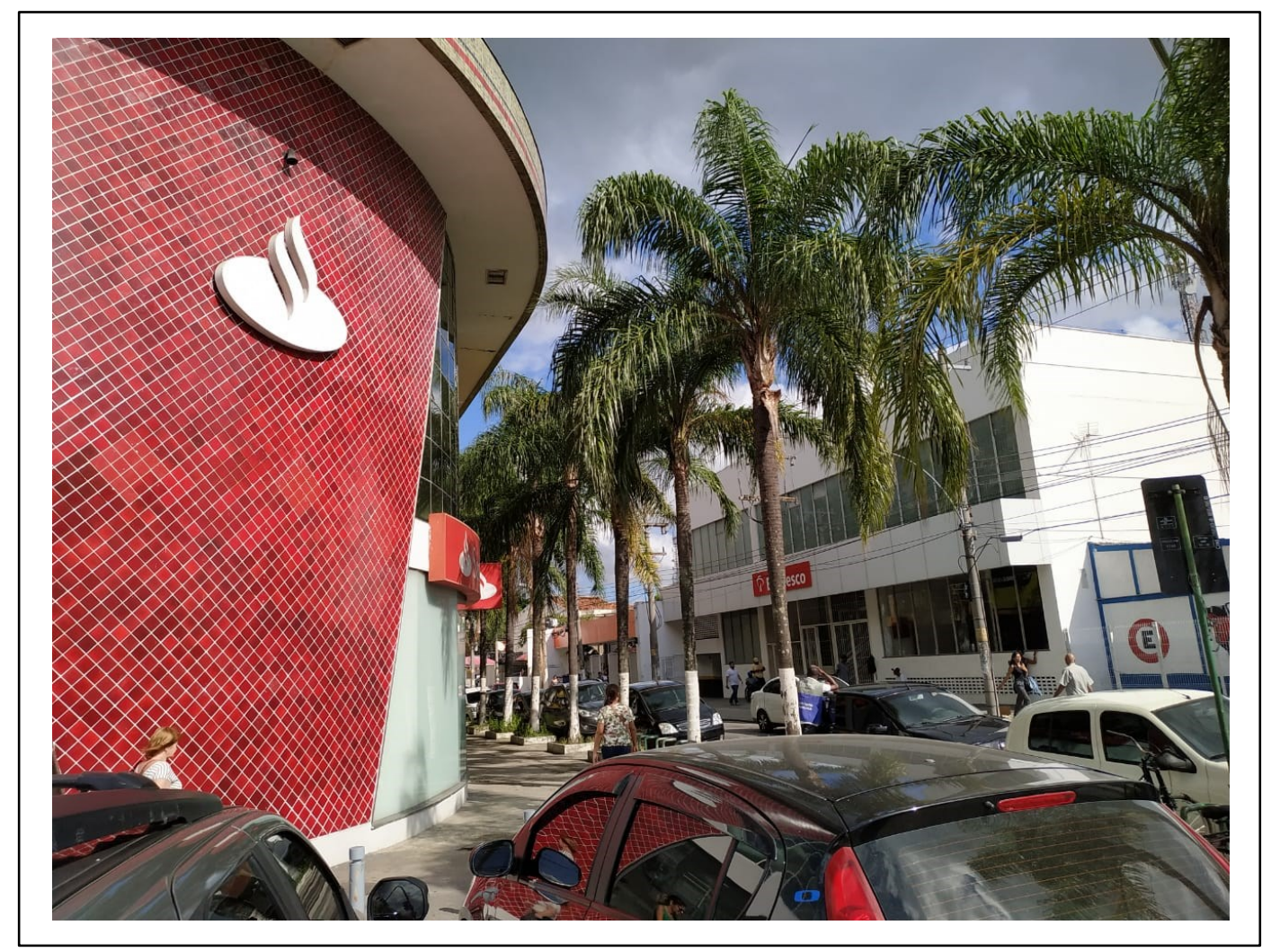

Fonte: BARATA, Paulo Henrique Araujo. O Sertão vira Calçadão... Op. cit., p. 64.

A expansão agressiva da oferta de bancos parece ter acompanhado a formação de um novo eixo comercial que compreenderia as vias que interligam o West ao centro de Campo Grande via Viaduto Alim Pedro. São nove agências nas vias e mais duas localizadas dentro do West Shopping. O grande número de residências a venda ou sendo alugadas e pontos comerciais fechados com placa de "aluga-se" parecem não afugentar o capital financeiro que continua a imprimir suas marcas na paisagem. Mais uma vez, os objetos materializados no espaço nos respondem sobre o momento da acumulação e produção capitalista do espaço.

Pela Estrada Rio do "A", o intenso fluxo de automóveis impede a fluidez do movimento causando ansiedade naqueles que precisam chegar nos compromissos agendados. A visão da imensa fila de carros, ônibus e até caminhões que torna um trajeto de pouco menos de três minutos em uma jornada de até 40 minutos em nada lembra aquele antigo bairro rural. A urgência do tempo do espaço urbano ruge nos ouvidos daqueles presos no engarrafamento pelo constante som das buzinas apitando e pedindo que os veículos a frente se movimentem. Qualquer avanço de 20 metros é frustrado por mais algum tempo de total imobilização e a frustração aumenta de intensidade quando percebemos a subida do viaduto Prefeito Alim Pedro tomada por automóveis e, por isso, completamente parada. A imobilidade do trânsito transmite a sensação de impotência frente a modernidade estampada na paisagem. Do ponto mais alto do viaduto podemos ver grande parte da recente produção comercial e residencial na 
forma de prédios. A paisagem nesse trecho da Zona de Comércio e Serviços 2 foi transformada ao ponto de ser semelhante a qualquer outro bairro tido como emergente da Zona Suburbana.

Figura 24 - Viaduto Prefeito Pedro Alim engarrafado com os prédios comerciais Business Premium e Plaza Offices, e prédios residenciais, ao fundo.

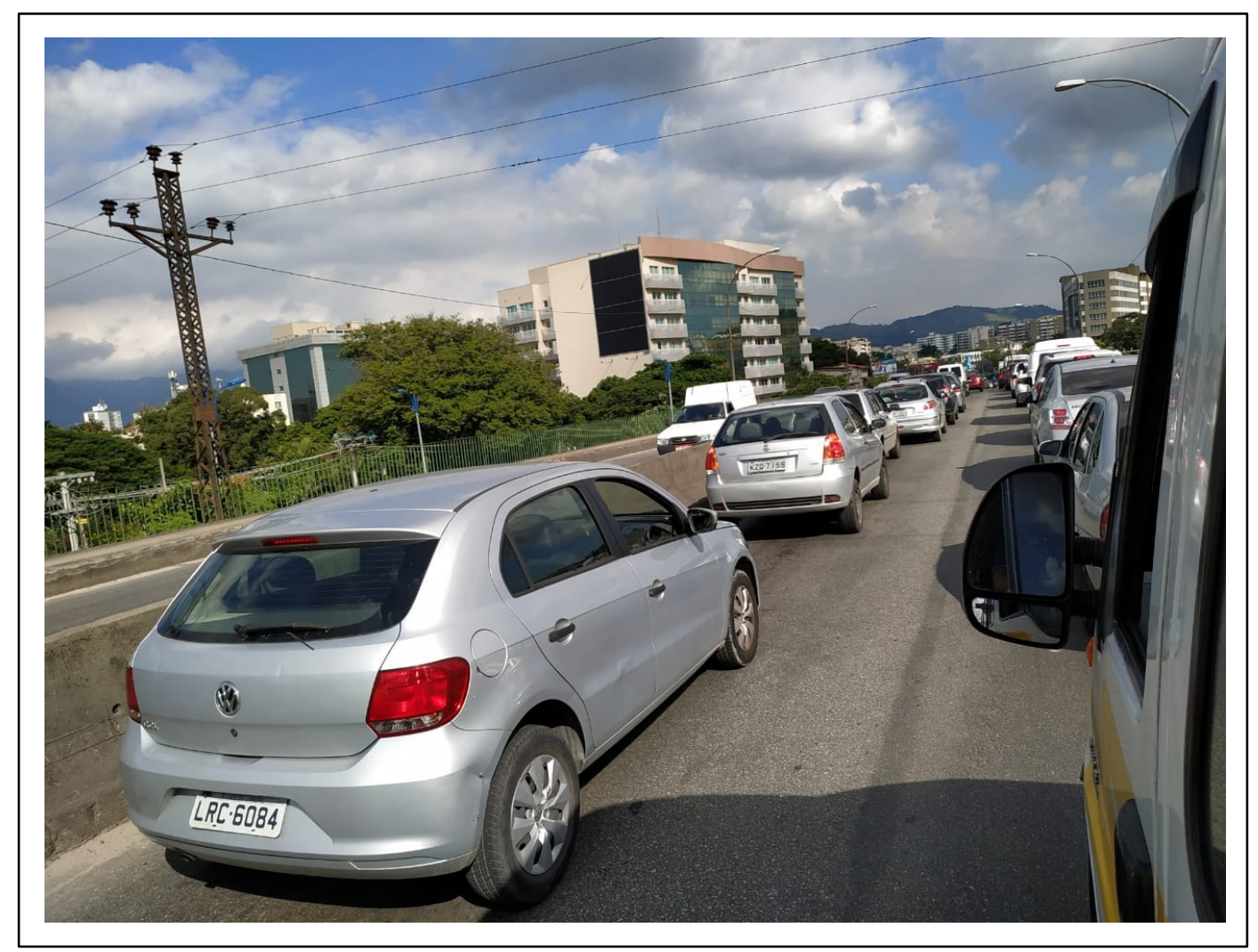

Fonte: BARATA, Paulo Henrique Araujo. O Sertão vira Calçadão... Op. cit., p. 65.

A fachada espelhada do prédio comercial Bussiness Premium reflete o trânsito congestionado, enquanto os muitos prédios a frente revelam que a outrora paisagem rural está irremediavelmente transformada para feições tipicamente urbanas. Os fluxos e os objetos construídos confirmam: aquele bairro outrora rural não existe mais. ${ }^{24}$

\footnotetext{
${ }^{24}$ As pesquisas de Alexandre Lourenço e Paulo Barata abordam, sob diferentes perspectivas, o processo de transformação do rural para o urbano e a produção do espaço urbano no bairro de Campo Grande. Cf.: LOURENÇO, Alexandre da Silva. O bairro de Campo Grande: representações, impasses, perspectivas e particularidades de "um" processo de reestruturação urbana. 2009. Dissertação (Mestrado em Geografia) - Instituto de Geografia da Universidade do Estado do Rio de Janeiro, Rio de Janeiro; BARATA, Paulo Henrique Araujo. O Estado capitalista e a produção desigual do espaço no bairro de Campo Grande, Rio de Janeiro. 2012. Dissertação (Mestrado em Geografia) - Instituto de Geografia da Universidade do Estado do Rio de Janeiro, Rio de Janeiro; BARATA, Paulo Henrique Araujo. O Sertão vira Calçadão: $A$ transformação do rural em urbano em Campo Grande, Rio de Janeiro, ao longo do século XX. 2019. Tese (Doutorado em Geografia) - Instituto de Geografia da Universidade do Estado do Rio de Janeiro, Rio de Janeiro.
} 


\section{Referências}

\section{Fontes}

\section{Obras de Referência}

Índice de Desenvolvimento Humano Municipal (IDH), por ordem de IDH, segundo os bairros ou grupo de bairros - 2000. DataRio. Rio de Janeiro: Prefeitura da Cidade do Rio de Janeiro Secretaria Municipal de Urbanismo - Instituto Pereira Passos - Diretoria de Informações Geográficas: 2010.2 Disponível em: http://www.data.rio/datasets/58186e41a2ad410f9099af99e46366fd. Acesso em: 19 fev. 2019.

População - Bairro: Campo Grande. Bairros Cariocas. (Recurso Eletrônico). Rio de Janeiro: Prefeitura da Cidade do Rio de Janeiro - Secretaria Municipal de Urbanismo - Instituto Pereira Passos / Diretoria de Informações Geográficas. Disponível em: http://pcrj.maps.arcgis.com/apps/MapJournal/index.html?appid=7fe1b0d463e34b3b9ca2fafd5 0c3df76\#. Acesso em: 19 fev. 2019.

\section{Imagens}

ARQUIVO Nacional - Rio de Janeiro. Fundo Agência Nacional, Série Fotografias, Sub-série Eventos, doc. 7086. Fachada do Hospital Rocha Faria, Campo Grande, Rio de Janeiro, RJ. 1942. Negativo fotográfico, $9 \mathrm{~cm}$., p\&b. Disponível em: http://sian.an.gov.br/sianex/consulta/Pesquisa_Livre_Painel_Resultado.asp?v_CodReferencia_i $d=1481485 \& v \_a b a=1$. Acesso em: 20 fev. 2019.

ARQUIVO Nacional - Rio de Janeiro. Fundo Agência Nacional, Série Fotografias, Sub-série Eventos, doc. 6222. Inauguração da passagem inferior da Estação de Campo Grande, Estrada de Ferro Central do Brasil, Rio de Janeiro. Negativo Fotográfico, $9 \mathrm{~cm}$, p\&b. Disponível em: http://sian.an.gov.br/sianex/Consulta/Pesquisa_Livre_Painel_Resultado.asp?v_CodReferencia_ id=1479238\&v_aba=1. Acesso em: 20 fev. 2019.

BARATA, Paulo Henrique Araujo. O Sertão vira Calçadão: A transformação do rural em urbano em Campo Grande, Rio de Janeiro, ao longo do século XX. 2019. Tese (Doutorado em Geografia) - Instituto de Geografia da Universidade do Estado do Rio de Janeiro, Rio de Janeiro, p. 40;43; 44; 46; 48; 50; 52; 55; 57; 58; 59; 60; 61; 63; 64; 65; 157; 215; 219;

Blog do Maninho Bonzão. (Blog). [Colégio Belisário Pena]. 2012. Disponível em: http://joseluizmano.blogspot.com/2012/08/ano-de-1952.html. Acesso em: 20 fev. 2019.

LAMES, Cayo. Igreja Nossa Senhora dos Desterros. 2018. Facebook. (Plataforma Eletrônica). Disponível

em:

https://www.facebook.com/photo?fbid=361283014682673\&set=a.122656968545280. Acesso em: 27 dez. 2018.

RAVAGANI. [Colégio Belisário Pena]. [s./d.]. Disponível em: https://www.facebook.com/belisariocg/. Acesso em: 20 fev. 2019.

MELO, Uilton Soares de. [s/d]. [Da série: Campo Grande das minhas lembranças...]. 2018. Facebook. (Plataforma Eletrônica). Disponível em: https://www.facebook.com/photo.php?fbid=2404301746253713\&set=a.1101842733166294\&t ype=3\&theater. Acesso em: 19 fev. 2019. 


\section{Publicações Impressas}

Campo Grande - Capital do Sertão. Correio da Manhã, Rio de Janeiro, 12 jan. 1970.

\section{Publicações Online}

MELO, Uilton Soares de. [Da série: Campo Grande das minhas lembranças...]. Facebook. (Plataforma Eletrônica). 2018.2 Disponível em: https://www.facebook.com/photo.php?fbid=2404301746253713\&set=a.1101842733166294\&t ype=3\&theater. Acesso em: 20 fev. 2020.

\section{Bibliografia}

ABREU, Maurício de. A evolução urbana do Rio de Janeiro. Rio de Janeiro: Prefeitura da Cidade do Rio de Janeiro, 2008.

BARATA, Paulo Henrique Araujo. O Estado capitalista e a produção desigual do espaço no bairro de Campo Grande, Rio de Janeiro. 2012. Dissertação (Mestrado em Geografia) Instituto de Geografia da Universidade do Estado do Rio de Janeiro, Rio de Janeiro.

BARATA, Paulo Henrique Araujo. O Sertão vira Calçadão: A transformação do rural em urbano em Campo Grande, Rio de Janeiro, ao longo do século XX. 2019. Tese (Doutorado em Geografia) - Instituto de Geografia da Universidade do Estado do Rio de Janeiro, Rio de Janeiro.

GODOY, Paulo Roberto Teixeira (org.). História do Pensamento Geográfico e epistemologia em Geografia. São Paulo: Ed. UNESP, 2010.

HOLANDA, Sérgio Buarque. Raízes do Brasil. 26a ed. São Paulo: Companhia das Letras, 1995.

LEFEBVRE, Henri. De lo rural a lo urbano. Barcelona: Península, 1978.

LOURENÇO, Alexandre da Silva. O bairro de Campo Grande: representações, impasses, perspectivas e particularidades de "um" processo de reestruturação urbana. 2009. Dissertação (Mestrado em Geografia) - Instituto de Geografia da Universidade do Estado do Rio de Janeiro, Rio de Janeiro.

LYNCH, Kevin. A imagem da cidade. São Paulo: Martins Fontes, 1999.

MORAES, Antonio Carlos Robert. Ideologias Geográficas. São Paulo: Annablume, 2005.

PINTAUDI, Silvana. Anotações sobre o espaço do comércio e do consumo. In: CARRERAS, Carles; PACHECO, Susana Mara Miranda. Cidade e comércio: a rua comercial na perspectiva internacional. Rio de Janeiro: Armazém das Letras, 2009.

SANTOS, Milton. A Natureza do Espaço: Técnica e Tempo, Razão e Emoção. São Paulo: EdUSP, 2006.

SANTOS, Milton. Espaço e método. São Paulo: Nobel, 1985.

SANTOS, Milton. Espaço e Sociedade. Petrópolis, RJ: Vozes, 1980.

SOUZA, Marcelo Lopes de. Os conceitos fundamentais da pesquisa sócio-espacial. Rio de Janeiro: Bertrand Brasil, 2013. 